\title{
Image and Chalcedonian Eucharistic doctrine: a re-evaluation of the Riha paten, its decoration and its historical context
}

\begin{abstract}
The iconography of the Communion of the Apostles, a theme well established in Byzantine art after Iconoclasm, first appears in a securely dated context in the silver patens from Riha and Stuma. These silver plates were produced in Constantinople sometime between 575 and 578. The iconography with the twofold depiction of Christ is usually explained as a reflection of the liturgical practice of the Eucharist, namely, as a reflection of the two actors in the Eucharistic rite, the priest and a deacon distributing bread and wine. I argue instead that during the early Byzantine period the twofold depiction of Christ is an expression of the two natures of Christ directed against the Miaphysites. I propose that the exceptional appearance of the scene in the two early Byzantine silver patens from church treasures from northern Syria is likely to be explained by its Christological significance with regard to Chalcedonian Eucharistic doctrine during the persecution of the Miaphysites in the 570s.
\end{abstract}

\footnotetext{
Adresse: Dr. Benjamin Fourlas, Leibniz-WissenschaftsCampus - Byzanz zwischen Orient und Okzident - Mainz/Frankfurt; Römisch-Germanisches Zentralmuseum, Leibniz-Forschungsinstitut für Archäologie, Ernst-Ludwig-Platz 2, 55116 Mainz, DeUTSCHLAND; fourlas@rgzm.de
}

The Dumbarton Oaks Collection houses one of the masterpieces of early Byzantine ecclesiastical silverware, the so-called Riha paten (fig. 1). ${ }^{1}$ The dish is espe-

\footnotetext{
The argument of this paper and especially the Christological aspect was developed in close collaboration with my colleague PD Dr Stefan Albrecht (Mainz) while he was working on his paper on the words of institution on middle Byzantine Eucharistic vessels (footnote 34). I would like to thank Prof. Dr Wolfram Brandes (Frankfurt) and Prof. Dr Vasileios Marinis (New Haven) for providing valuable insights, Prof. Dr Antony Eastmond (London) for providing fig. 11 and my colleague Michael Ober M.A. for the excellent drawings and the map. I am grateful to Vasileios Marinis for the thorough proofreading of the English manuscript. This publication was supported by the Open Access Funds of the Römisch-Germanisches Zentralmuseum.

1 Inventory no. BZ.1924.5. Principle references: N. AsutAy-EFFEnBerger/ A. EFfEnberger, Byzanz. Weltreich der Kunst. München 2017, 109f. fig. 38; S. ZwIRN, Riha Paten (Diskos) with the Communion of the Apostles, in G. Bühl (ed.), Dumbarton Oaks. The Collections. Washington
} 
cially remarkable for its decoration. Its subject matter is not an illustration of the Last Supper as narrated in the Gospels, a scene that is attested in pictorial sources since the fifth century (fig. 4). ${ }^{2}$ Rather, it is a symbolic depiction of Christ

2008, 78f.; R. CoRmack / M. VASSILAKi (eds.), Byzantium 330-1453. London 2008, 383 no. 20 (G. BüHL); M. Mundell Mango, Silver from early Byzantium. The Kaper Koraon and related treasures. Baltimore 1986, 165 - 170 no. 35; J.M.C. TOYNBEE/ K. S. PAINTER, Silver picture plates of late antiquity: A.D. 300 to 700. Archaeologia 108 (1986), 15-65: 58 no. 80 pl. 30c; J.L. SCHRADER, Antique and early Christian sources for the Riha and Stuma patens. Gesta 18/1 (1979), 147 -156; P. ANGiolini Martinelli, Le patene argentee di Riha e Stûmâ. Corsi di Cultura sull'arte Ravennate e Bizantina. Ravenna - 10-23 Marzo 1974. Ravenna 1974, 31-45; M.C. Ross, Catalogue of the Byzantine and medieval antiquities in the Dumbarton Oaks Collection I. Washington, DC 1962, $12-15$ no. 10 pl. $11-13$, all with references to preceding bibliography. For an extensive bibliography see http://museum.doaks.org/Obj23428?sid=210\&x= 1534\&sort=76 (viewed July 8th 2021).

2 For the iconography of the Last Supper see E. Lucchesi Paldi / L. Hoffscholte, Abendmahl. Lexikon der christlichen Ikonographie I (1968), 10 - 18; K. WeSSEL, Abendmahl. RbK I (1966), 1 11; K. WesseL, Abendmahl und Apostelkommunion. Recklinghausen 1964. According to one of the tituli of Ambrose the scene was probably already depicted in the Basilica Ambrosiana at Milan by the late fourth century. F.W. Deichmann, Ravenna. Hauptstadt des spätantiken Abendlandes II 1. Wiesbaden 1974, 173; S. F. Lubian, Disticha Sancti Ambrosii. Introduzione, testo criticamente riveduto, traduzione e commento. CC, Lingua Patrum, 10. Turnhout 2017, $104 \mathrm{f}$. Nr. II (21) (p. 116-125). The scene rarely occurs during the fifth and sixth centuries. The ivory book cover at Milan, the mosaic panel at Sant'Apollinare Nuovo at Ravenna, the depiction on the column of the ciborium at San Marco at Venice, the miniatures in the Gospels of St Augustine at Cambridge (Corpus Christi College, MS 286, fol. 125) and the Rossano Gospels (fig. 4) are the only pictorial testimonies from this period. U. KUDER, Die Eucharistie in Bildwerken vom frühen 3. bis zum 7. Jahrhundert, in D. Hellenholm/D. Sänger (eds.), The Eucharist - its origins and contexts. Sacred meal, communal meal, table fellowship in late antiquity, early Judaism, and early Christianity, II. Wissenschaftliche Untersuchungen zum Neuen Testament, 376. Tübingen 2017, 1297 - 362: 1320-1324 figs. 12 -13. 15. 19-25. Book cover at Milan: J. SPIER (ed.), Picturing the Bible. The earliest Christian art. Fort Worth 2007, 256-258 no 76B; W. F. VoLBACH, Elfenbeinarbeiten der Spätantike und des frühen Mittelalters. Kataloge vor- und frühgeschichtlicher Altertümer, 7. Mainz ${ }^{3} 1976$, 84 f. no 119. - Mosaic panel at Ravenna: J. DRESKEN-WEILAND, Die frühchristlichen Mosaiken von Ravenna. Bild und Bedeutung. Regensburg 2016, 137 -140; Deichmann, ibid. 173 f. - Relief column at Venice: Kuder, ibid., 1322 f. figs. 18-20; J. DreskEN-WeILAND, Darstellungen neutestamentlicher Mahlszenen auf den Ciboriumssäulen von San Marco in Venedig. Antiquité Tardive 27 (2019), 241-253: 250f. fig. 9. - Rossano Gospels: P. Sevrugian, Der Rossano-Codex und die Sinope-Fragmente. Miniaturen und Theologie. Manuskripte zur Kunstwissenschaft, 35. Worms 1990, 57 f. pl. 10-11. For the miniatures of the Gospels of St Augustine dates from the sixth to the eighth century are debated: F. WoRmaLD, The miniatures in the Gospels of St. Augustine. Cambridge, Corpus Christi College MS 286, in F. Wormald, Collected writings. Studies in medieval art from the sixth to the twelfth centuries. Oxford 1984, 13 - 35: 30 fig. 8. Cf. R. SöRRIES, Christlich-antike Buchmalerei im Überblick. Wiesbaden 1993, 34-36 pl. 13. - Chorikios of Gaza attests a depiction of the Last Supper in the Church of St Sergius at Gaza (Laudatio Marciani I § 72, ed. R. Foerster/E. RichtSTEIG, Choricii Gazaei 
standing behind an altar and distributing bread and wine to the twelve apostles using a paten and a chalice. The image combines the aspect of Christ presiding over the Last Supper understood in a sensus litteralis with the aspect of Christ who, in an allegorical sense, that is, as a priest, distributes the Eucharistic elements. ${ }^{3}$ The iconography evidently reflects liturgical practice and emphasizes the paten's function as a Eucharistic vessel. Ruth LEADER-NEWBY stresses the self-reflexive character of the image: it combines a representation of the ritual in which the plate would have been used with an invocation of the institution of the same ritual by Christ. ${ }^{4}$ Thus the paten's decoration underscores the idea that both the celebrant and the participant in the Eucharist are part of the reenactment and repetition of the historical Last Supper. ${ }^{5}$

On the rim an inscription is chased into the silver and highlighted by niello fillings. It characterizes the vessel as a votive:

\section{$\dagger$ VחEP ANAחAVCEWC CEPIIAC IWANNOV $k(\alpha \mathrm{i}) \Theta \in O \triangle O C I O V k(\alpha \mathrm{i})$ CWTHPIAC MEГA^OV $k(\alpha i)$ NONNOV $k(\alpha i)$ TWN AVTWN TEKNWN}

† For the repose (of the soul) of Sergia (daughter? and?) of Ioannes, and of Theodosios, and for the salvation of Megalos [Megas] and of Nonnous and of their children ${ }^{6}$

Imperial stamps on the backside of the paten indicate that the paten was manufactured in Constantinople ${ }^{7}$ during the reign of Emperor Justin II (565-578)

Opera. Lipsiae 1929): H.G. THÜмmEL, Die Schilderung der Sergioskirche in Gaza und ihrer Dekoration bei Chorikios von Gaza, in U. Lange/R. Sörries (eds.), Vom Orient bis an den Rhein. Begegnungen mit der Christlichen Archäologie Peter Poscharsky zum 65. Geburtstag. Christliche Archäologie, 3. Dettelbach 1997, 49-64: 59, 63.

3 Cf. D. KRUeger, Liturgical subjects. Christian ritual, biblical narrative, and the formation of the self in Byzantium. Philadelphia 2014, 113; W.T. Woodfin, Celestial hierarchies and earthly hierarchies in the art of the Byzantine Church, in P. Stephenson (ed.), The Byzantine world. London 2010, 313-319: 310.

4 R. LEADER-NEWBY, Silver and society in late antiquity. Aldershot 2004, $92 \mathrm{f}$.

5 Cf. Y.D. VARALIS, The Communion of the Apostles: thoughts on artistic, spatial and liturgical

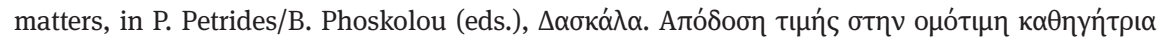

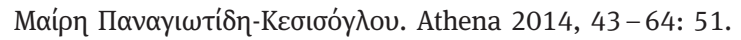

6 For the inscription and its translation see G. Downey, The inscription on a silver chalice from Syria in the Metropolitan Museum of Art. AJA 55 (1951), 349-353: 350 with note 6; MundeLL MANGo, Silver (as footnote 1 above), 166. 169; L. JALABERT/R. MOUTERDE, Inscriptions grecques et latines de la Syrie II. Bibliothèque archéologique et historique, 32. Paris 1939, 378 no. 695. On the formula of the inscription see also J. WiтT, "Hyper Euches". In Erfüllung eines Gelübdes. Untersuchungen zum Votivwesen in frühbyzantinischer Zeit. Diss. Univ. Erlangen-Nürnberg 2006, $189 \mathrm{f}$.

7 Ample evidence indicates that silver objects with mainly five stamps of the "imperial" series were manufactured in Constantinople with very few exceptions. E. CRUIKsHANK DodD, The location of silver stamping: evidence from newly discovered stamps, in S. A. Boyd/M. Mundell 


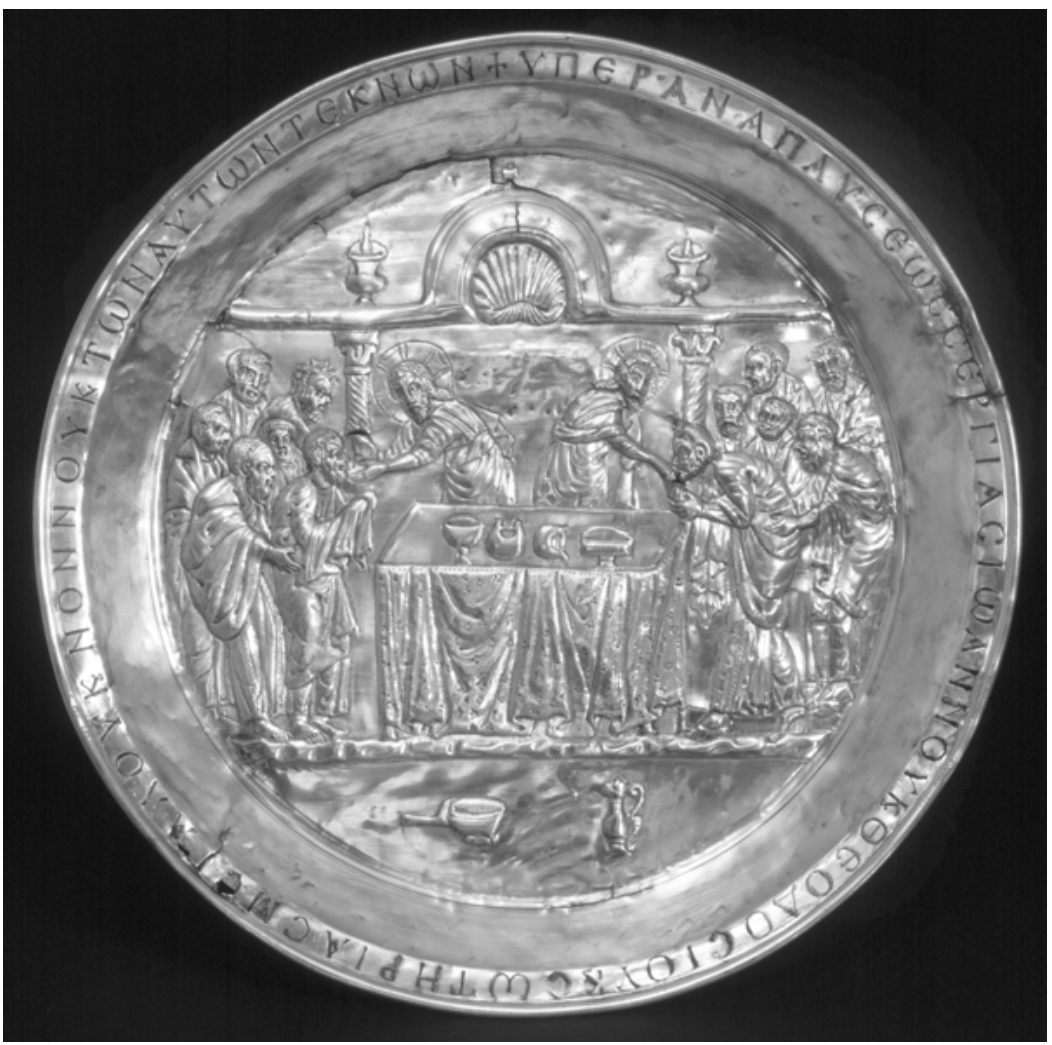

Fig. 1. So-called Riha paten [with kind permission by Dumbarton Oaks Collection].

Mango (eds.), Ecclesiastical silver plate in sixth-century Byzantium. Washington, DC 1992, 217 223. - M. Mundell MANGo, The purpose and places of Byzantine silver stamping, ibid., 203 216: $207-211$ doubts an exclusive production of objects marked with the "imperial" series in the capital and suggested that these stamps could have been applied in any of the mints or thesauri of the Eastern prefecture. But apart from two objects with stamps referring to Antioch and another one possibly related to Tarsos there are no secure indications to challenge an application of "imperial" stamps predominantly in Constantinople. On this topic see also B. FourLAs, Eine frühbyzantinische Silberschale mit der Darstellung des heiligen Theodor. Jahrbuch des Römisch-Germanischen Zentralmuseums 55 (2008), 483-528: 497 f. and E. CRUiKsHANK Dodd / M. Aimone, Silver objects with stamps, in M. Aimone, The Wyvern Collection. Byzantine and Sasanian silver, enamels and works of art. London 2020, $463 \mathrm{f}$. 


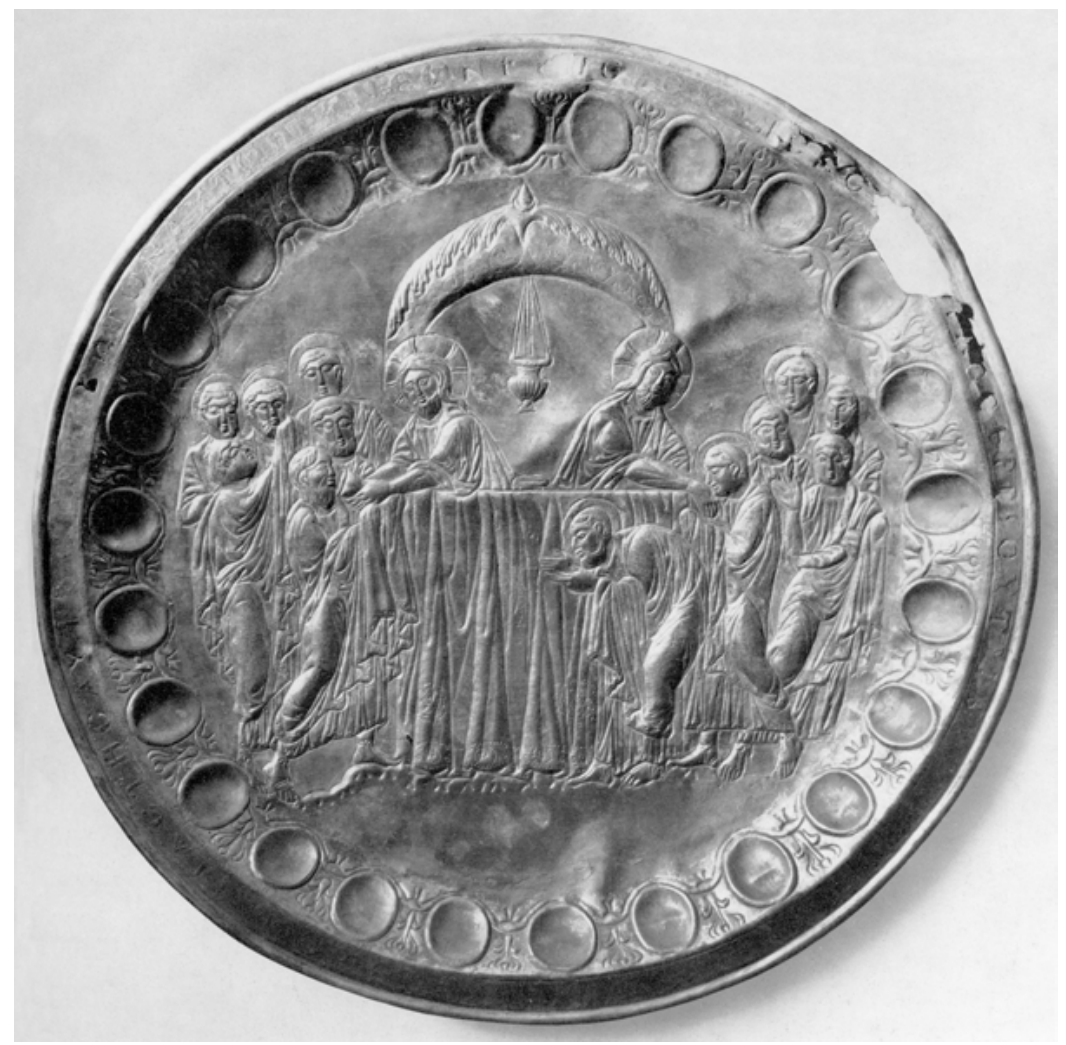

Fig. 2. So-called Stuma paten [after W. F. Volbach, Frühchristliche Kunst. Die Kunst der Spätantike in West- und Ostrom. München 1958, pl. 247]

while Theodore held the office of comes sacrarum largitionum in $575 / 76 .{ }^{8}$ It is communis opinio that Megas is the homonymous dignitary who belonged to the highest-ranking imperial officials by $587 / 588 .^{9}$ A paten from the so-called

8 E. Cruikshank Dodd, Byzantine silver stamps. DOS 7. Washington, DC 1961, 95 no. 20 gives 577 for his office but his tenure of office was revised to 575/76 by R. DELMAIRE, Les responsables des finances imperials au Bas-Empire romain (IVe-VIe s.). Études prosopographiques. Collection Latomus, 203. Bruxelles 1989, 283-285. Cf. J. R. MARTindale/ A. H. M. JonEs/J. MoRRIS, Prosopography of the Later Roman Empire III. Cambridge 1992, 1255 f. s.v. Theodorus 34. 9 Ibid., 870 f. s.v. Megas 2; Mundell Mango, Silver (as footnote 1), 9. D. Feissel, Magnus, Megas et les curateurs des "maisons divines" de Justin II à Maurice. TM 9 (1985), 465-476 pointed out that he is not identical with Mangus the Syrian as A. EFFEnBERgER, Bemerkungen 


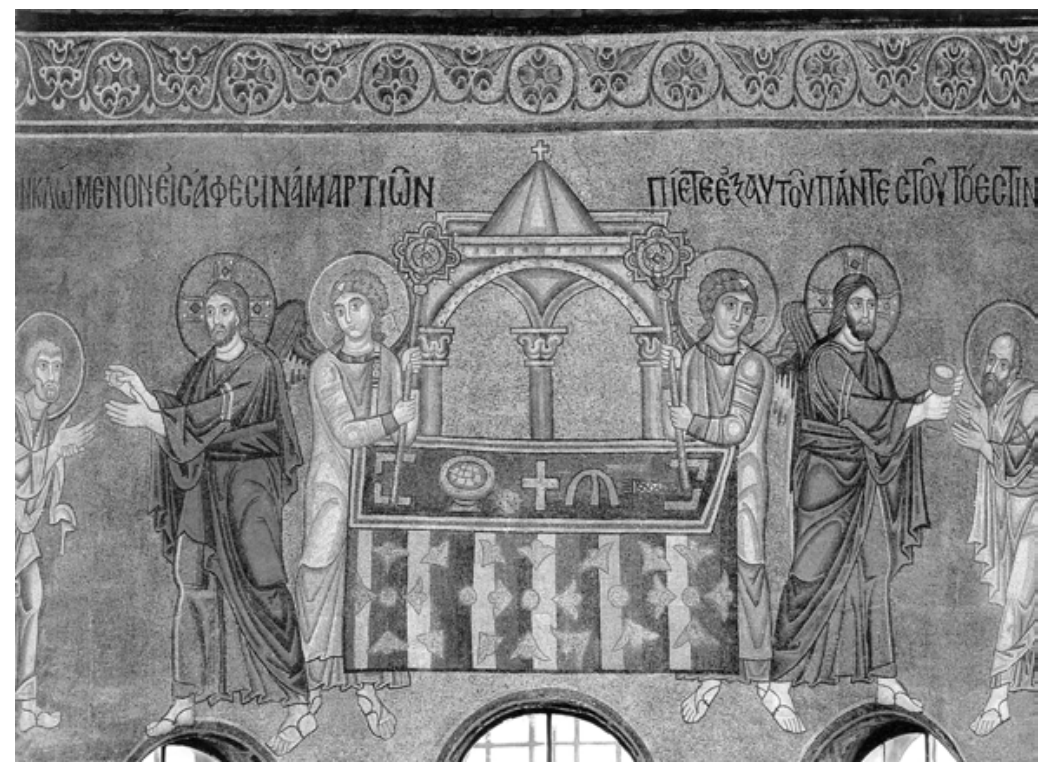

Fig. 3. Kiev, Mosaic in the sanctuary of St. Sophia [after A. Cutler/J.-M. Spieser, Das mittelalterliche Byzanz 725-1204. Universum der Kunst 41. München 1996, 275].

Stuma treasure represents a "twin" piece to the Riha vessel and, according to its votive inscription, was dedicated by a tribunus and argyroprates named Sergios. ${ }^{10}$ Imperial stamps date the manufacture of this vessel to the years $577 /$ 78 (fig. 2). ${ }^{11}$

Both vessels are remarkable because they represent the earliest securely dated examples of the Communion of the Apostles (Apostelkommunion), a motive that circulated widely in Byzantine art after Iconoclasm (fig. 3). ${ }^{12}$ The scene ap-

zum "Kaper-Koraon-Schatz", in Tesserae. Festschrift für Josef Engemann. JbAC Ergbd. 18. Münster 1991, 241-277: 253f. assumes.

10 Istanbul, Archaeological Museum inventory no. 3759. Main references: Mundell MANGo, Silver (as footnote 1), 159-164 no. 34; ToynbeE/PAinter, Picture plates (as footnote 1), $57 \mathrm{f}$. no. 79 pl. 30b; Cruikshank Dodd, Silver stamps (as footnote 8), 108f. no. 27.

11 Cruikshank Dodd, Silver stamps (as footnote 8), 108f. no. 27. - The dating relies on the tenure of Peter as comes sacrarum largitionum. See Delmaire, Les responsables (as footnote 8), 285.

12 For basic bibliography see K. WesseL, Apostelkommunion. RbK I (1966), 239-245; WesSEL, Abendmahl (as footnote 2 above); E. Lucchesi PALLI, Apostelkommunion. Lexikon der christlichen Ikonographie I (1968), 173-176; W.C. LoERKE, The monumental miniature, in K. Weitzmann/ W.C. Loerke/E. Kitzinger/H. Buchthal, The place of book illumination in Byzantine 


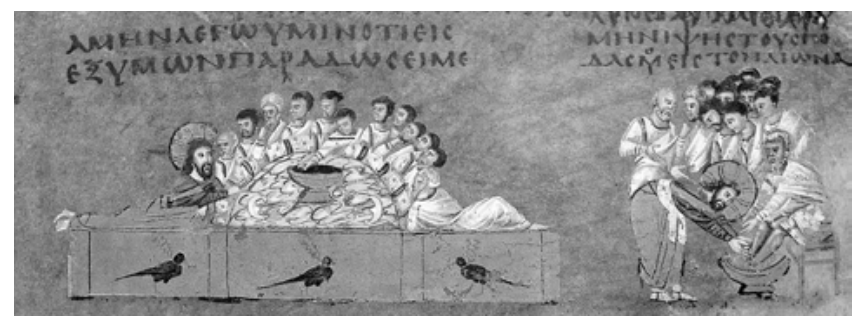

Fig. 4. Rossano Gospels. Rossano, Museo Diocesano, Codex unicus fol. 3r, Last Supper and Washing of the feet [@ Mons. Antonio De Simone, Arcidiocesi di Rossano-Cariati, http:// www.unesco.org/new/en/communication-and-information/resources/multimedia/photo-galle ries/preservation-of-documentary-heritage/photos-memory-of-the-world-register/2015/italythe-codex-purpureus-rossanensis/]

pears in several variations in book illumination, icons, and monumental painting. William C. LOERKE emphasized that the fundamental point of the Communion of the Apostles was to demonstrate explicitly the two elements of the Sacrament, bread and wine, and that the subject demanded a central composition focused around the $\operatorname{altar}^{13}$ as in the Riha paten (fig. 1). There, a chalice on conical foot with a round node and a paten with a high rim and foot ring appear on a cloth-covered altar. Between these liturgical vessels, there are two crescentshaped objects. They are often wrongly interpreted as wineskins ${ }^{14}$ or liturgical

art. Princeton 1975, 78 -97 figs. 12-24; S.E.J. GeRSTEL, Beholding the sacred mysteries. Programs of the Byzantine sanctuary. Monographs on the Fine Arts, 56. Seattle 1999, 48-67; A.G.

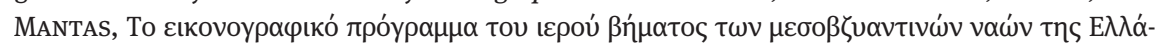
$\delta \alpha \varsigma$ (843-1204). Bibliotheke Sophia N. Saripoulou, 95. Athena 2001, 125-134; VARALIs, Communion (as footnote 5 above), 43 - 64 figs. 1-2; C. JoLIVET-LÉvy, Images des pratiques eucharistiques dans les monuments byzantins du Moyen Âge, in N. Bériou/B. Caseau D. Rigaux (eds.), Pratiques de l'eucharistie dans les Églises d'Orient et d'Occident (Antiquité et Moyen Âge), I. L'institution. Paris 2009, 161 - 200: 162 - 174 figs. 1-8; R. BETANCOURT, The Thessaloniki epitaphios: notes on use and context. GRBS 55 (2015), 489-535: 490 - 496 and especially the dis-

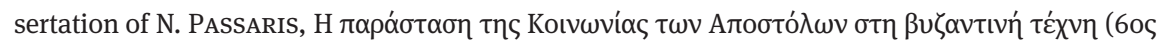

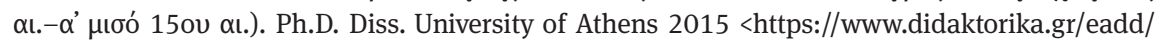
handle/10442/36576> with an extensive catalogue of the pictorial sources. See also V. MARINIs, A reconsideration of the Communion of the Apostles in Byzantine Art. Studies in Iconography 42 (2021), 1-20.

13 LOERKE, Monumental miniature (as footnote 12 above), 79.

14 E. g. KruEger, Liturgical subjects (as footnote 3 above), 113; VARALis, Communion (as footnote 5), 48; A. LAZARIDOU (ed.), Transition to Christianity. Art of late antiquity, 3rd-7th century AD. New York 2011, 142 f. no. 106 (S. ZwIRN); LEADER-Newby, Silver (as footnote 4), 92; S. A. BoyD, Art in the service of the liturgy: Byzantine silver plate, in L. Safran (ed.), Heaven on earth. Art and church in Byzantium. University Park 2000, 152 - 185: 175; Mundell MANGo, Silver (as 
vessels ${ }^{15}$ but they are certainly bread loaves of a specific form attested in a number of late antique banquet scenes. ${ }^{16}$ Christ is depicted twice behind the altar while two groups of six apostles each approach from either side. The Lord is disposing wine from a chalice to the first apostle on the left, and he is handing a piece of bread to the first apostle on the right who is receiving it with his raised left hand while kissing Christ's hand (Handkommunion). The whole scene is placed on an irregular ground remindful of landscape images. The epistyle, which is supported by two columns with two lamps on top, is a pictorial element remindful of a high templon or chancel barrier and thus suggests a church setting. ${ }^{17}$ At the bottom of the scene, below the ground level under the altar,

footnote 1 above), 170; ToyndeE/PAinter, Picture plates (as footnote 1 above), 58 and E. CRUiKSHANk DodD, Byzantine silver treasures. Monographien der Abegg-Stiftung, 9. Bern 1973, 41 ("skins for wine and water").

15 Ross, Catalogue (as footnote 1 above), 12 counts four liturgical vessels on the altar.

16 They are named "pains de communion" already by J. LASsus, Sanctuaires chrétiens de Syrie. Essai sur la genèse, la forme et l'usage liturgique des édifices du culte chrétien, en Syrie, du IIIe siècle à la conquête musulmane. Bibliothèque archéologique et historique, 42. Paris 1947, 214 note 6. See especially the late antique banquet scene at Constanţa (Romania). The crescentshaped bread loafs can be compared to the examples depicted on the Rhia paten. A. BARBET, Le tombeau du Banquet de Constantza, in: Au royaume des ombres. La peinture funéraire antique. IVe siècle avant J.-C. / IVe siècle après J.-C. Exhibitions catalogue Saint-Romain-en-Gal - Viienne 8 octobre 1998-15 janvier 1999. Saint-Romain-en-Gal-Vienne/Paris 1998, 109 (fig.). 110. For further examples see J.R. WiLson, Caddeddi on the Tellaro. A late Roman villa in Sicily and its mosaics. Bulletin antieke beschaving, Supplement, 28. Leuven 2016, 94 with note 24 fig. 5.21; K.M.D. Dunbabin, The Roman banquet. Images of convivality. Cambridge 2003, fig. 76 pl. $13-14.16$.

17 R. WARLAND, Die Gegenwart des Heils. Strategien der Vergegenwärtigung in der frühbyzantinischen Kunst, in idem (ed.), Bildlichkeit und Bildorte von Liturgie. Schauplätze in der Spätantike, Byzanz und dem Mittelalter. Wiesbaden 2002, 51 - 74: 53; LOERKE, Monumental miniature (as footnote 12 above), 95. - On the reconstruction of the templon of the Hagia Sophia at Constantinople that was also carrying lamps see S.G. XYDIs, The Chancel barrier, solea and ambo of Hagia Sophia. The Art Bulletin 29 (1947), 1-24: 10. - For high chancel barriers supported by

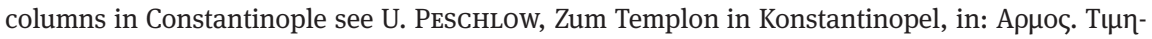

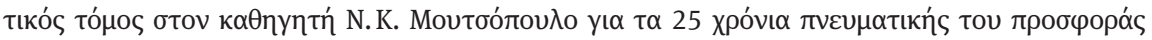

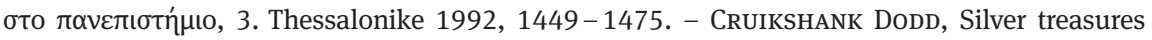
(as footnote 14 above), $40 \mathrm{f}$. interprets the columns with epistyle as indication for a ciborium. - VARALIS, Communion (as footnote 5 above), 48 with note 28 doubts an attribution to a templon as "Late Antique illustrations of chancel barriers are usually more elaborate". Maybe the silversmith adopted the iconographical model of an architectural backdrop as depicted on some of the famous David plates by adding lamps. LEADER-NewBy, Silver (as footnote 4 above), figs. $4.8-11$. 
are a bowl with a handle (trulla) and an ewer. ${ }^{18}$ Recently, a connection of these objects with the washing of the feet of the apostles, the episode that preceded the Last Supper, has been suggested..$^{19}$ But in Late Antique art these implements usually relate to the washing of the hands. ${ }^{20}$ In the Riha paten, they certainly hint at the ritual of the washing of the hands of the celebrant before communion. ${ }^{21}$

Judging from the known early Byzantine patens, this kind of decoration is rather uncommon. ${ }^{22}$ The depiction of the Communion of the Apostles, which is a rare scene in the early Byzantine period, on the Riha paten and its twin make these pieces even more special as they are the only surviving patens decorated with this subject matter. ${ }^{23}$ Ruth LEADER-NEwBY has rightly asked why such an appropriate decoration for a liturgical vessel is found only on these two closely connected patens from Syria and why the depiction of the Last Supper, the prototype of the Communion of the Apostles, is absent from the known early Byzantine church vessels. ${ }^{24}$ This could be just an accident of survival as

18 On the typology of the ewer see B. Niemeyer, Darstellungen von Silberkannen in der Figuralkunst des 2.-6. Jahrhunderts, in A. Kaufmann-Heinimann/M. Martin, Die Apostelkanne und das Tafelsilber im Hortfund von 1628. Trierer Silberschätze des 5. Jahrhunderts. Trierer Zeitschrift, Beiheft 35. Trier 2017, 175-210: 187 no. 1a.1.

19 VARalis, Communion (as footnote 5 above), $48 \mathrm{f}$.

20 See for example the picnic scene in the hunt mosaic at Caddeddi (Sicily) where a servant uses these implements to wash the hands of a "master": WiLson, Caddeddi (as footnote 16 above), 90 f. figs. 5.20 ; 5.22 .

21 H.U. NubER, Kanne und Griffschale. Ihr Gebrauch im täglichen Leben und die Beigabe in Gräbern der römischen Kaiserzeit. Bericht der Römisch-Germanischen Kommission 53 (1972), 1-232: 134-137. Already CRUIKSHANK DodD, Silver treasures (as footnote 14 above), 42 note 92 and Ross, Catalogue (as footnote 1 above), 12 identified these objects depicted on the Riha paten as being related to the washing of the hands. - On these implements as tools for the washing of the hands in liturgy see also M. BEGHELLI / J. PINAR, Corredo e arredo liturgico nelle chiese tra VIII e IX secolo. Jahrbuch des Römisch-Germanischen Zentralmuseums 60 (2013), 697 - 762: 707 fig. 6 and pl. 3,2. - On the rite of the washing of the hands see M. LüstRAETEN, "Ich will meine Hände waschen inmitten der Unschuld ...". Liturgietheologische Anfragen an

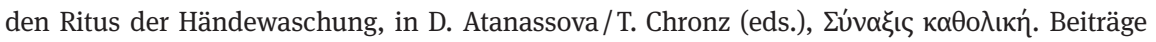
zu Gottesdienst und Geschichte der fünf altkirchlichen Patriarchate für Heinzgerd Brakmann zum 70. Geburtstag. Orientalia - patristica - oecumenica, 6. Münster 2014, 419-440 (esp. 426-429 on the rite within Byzantine liturgy).

22 Cf. LEADER-NewBy, Silver (as footnote 4 above), $93 \mathrm{f}$.

23 On two fakes of silver patens decorated with the Communion of the Apostles see the Appendix below.

24 LEADER-NEWBy, Silver (as footnote 4 above), 93. - On the surviving church vessels the Last Supper appears only after Iconoclasm. On a middle Byzantine paten at the Louvre (late ninthmid-tenth century) the scene is depicted in enamel: J. DuRAND, La "patène Stoclet" au Louvre. 
LEADER-NEWBY remarks. However, I am suggesting that the appearance of these vessels in Syria is not a coincidence but likely related to the significance of the scene in connection to the Christological debates of the time. As I will discuss below, this applies also to the two other pre-iconoclastic depictions of this scene in the Rossano and Rabbula Gospels, which likewise originate in the region and date to the sixth century (fig. 5-6. 8). ${ }^{25}$

In my opinion, a re-evaluation of the twofold depiction of Christ is the key to appraise the significance of the scene for their contemporary beholders. This detail is usually explained by the liturgical practice of the Eucharist. It is commonly assumed that it underscored that the liturgical practice of the Eucharistic rite is identical to the prototypical Communion of Christ and the apostles. Petra SEVRUGIAN suggested that the twofold depiction of Christ is inspired by the sequence of the distribution of bread and wine. ${ }^{26}$ But in most cases this detail is considered to reflect the two actors in the Eucharistic rite, the priest and a dea-

Revue du Louvre 4 (1998), 17 - 20; H.C. Evans / W. D. WiXom (eds.), The Glory of Byzantium. Art and Culture of the Middle Byzantine Era A.D. 843-1261. New York 1997, 67 f. no. 28 (H.C. Evans).

25 For the Rossano Codex an origin in Syria or Palestine and a dating to the sixth century (with caution to the mid-6th century) is proposed by SEvRUgian, Rossano-Codex (as footnote 2 above), 122 f. G. Cavallo, Codex Purpureus Rossaniensis. Guide Illustrate, 1. Roma 1992, 69-71 and IDEM, The Purple Codex of Rossano: book, object, symbol, in G. Cavallo/J. Gribonmot/W.C. Loerke (eds.), Codex Purpureus Rossaniensis commentarium. Codices Mirabiles, 1 = Codices Selecti Commentarium, 81. Roma/Graz 1987, 27 - 32 argues for a sixth-century date and a likely origin from Syria. W.C. LoERKE, The Rossano Gospels: the miniatures, in ibid., 164-167 suggests an origin in Syria or Palaestine in the second half of the 6th or maybe even the early 7th century. - The miniatures of the Rabbula Gospels (esp. fol. 1-12 and 14) were produced during the sixth century at a monastery in Syria and show stylistic resemblances to works of art of the justinianic era: M. BERNABò, Fantasie novecentesche, ripinture, fattura del codice, in M. Bernabò (ed.), Il tetravangelo di Rabbula. Firenze, Biblioteca medicea Laurenziana, Plut. 1.56. L'illustrazione del Nuovo Testamento nella Siria del VI secolo. Folia Picta 1. Roma 2008, 1-22: 16-19; IDEM, The miniatures of the Rabbula Gospels: postscript to a recent book. DOP 68 (2014), 343-358. The Text of the Gospels was produced independently of the illustrations (which were bound together only in the fifteenth century) at the monastery Beth Zabga that is most probably situated in Northern Syria near Riha. M. Mundell Mango, The Rabbula Gospels and other manuscripts produced in the late antique Levant, in M. Bernabò (ed.), Il tetravangelo di Rabbula. Firenze, Biblioteca medicea Laurenziana, Plut. 1.56. l'illustrazione del nuovo testament nella Siria del VI secolo. Folia Picta 1. Roma 2008, 113-126: 113 and IDEM, Where was Beth Zagba?, in C. Mango/O. Pritsak (eds.), Okeanos. Essays presented to Ihor Ševčenko on his Sixtieth Birthday by his Colleagues and Students. Harvard Ukrainian Studies, 7. Cambridge 1983, $405-430$ esp. 420-423. See also K.-P. TodT/B.A. VeSt, Syria (Syria Prote, Syria Deutera, Syria Euphratesia). TIB, 15. Wien 2015, 1013 s.v. Bet ZGB'.

26 Sevrugian, Rossano-Codex (as footnote 2 above), 61. 


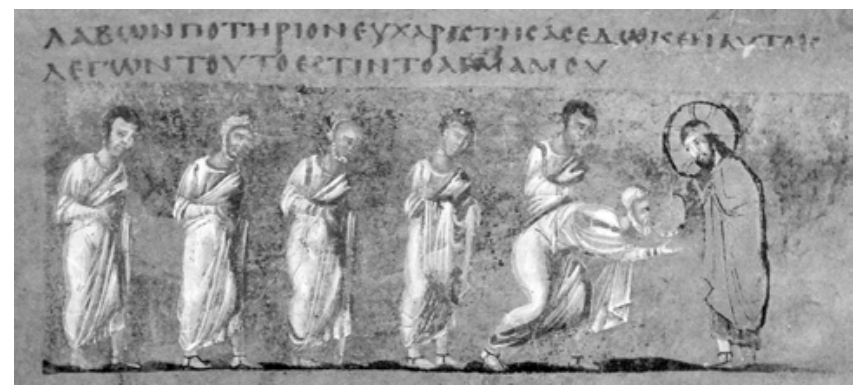

Fig. 5. Rossano Gospels. Rossano, Museo Diocesano, Codex unicus fol. 4r, Communion of the Apostles, distribution of wine [@ Mons. Antonio De Simone, Arcidiocesi di Rossano-Cariati, http://www.unesco.org/new/en/communication-and-information/resources/multimedia/photogalleries/preservation-of-documentary-heritage/photos-memory-of-the-world-register/2015/ italy-the-codex-purpureus-rossanensis/].

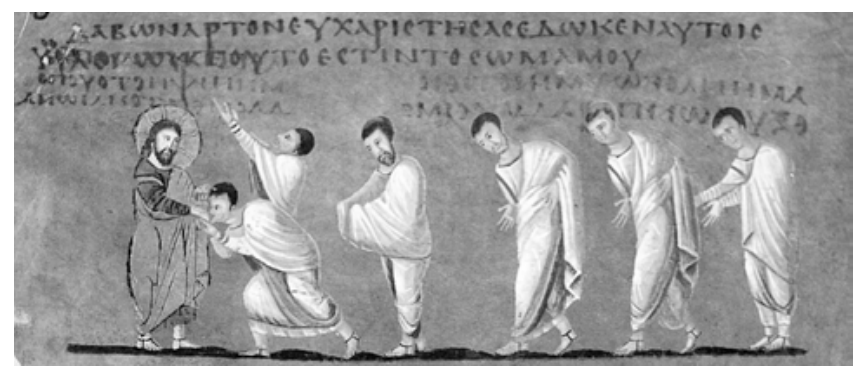

Fig. 6. Rossano Gospels. Rossano, Museo Diocesano, Codex unicus fol. 4v, Communion of the Apostles, distribution of bread [ $\odot$ Mons. Antonio De Simone, Arcidiocesi di Rossano-Caariati, http://www.unesco.org/new/en/communication-and-information/resources/multimedia/ photo-galleries/preservation-of-documentary-heritage/photos-memory-of-the-world-register/ 2015/italy-the-codex-purpureus-rossanensis/].

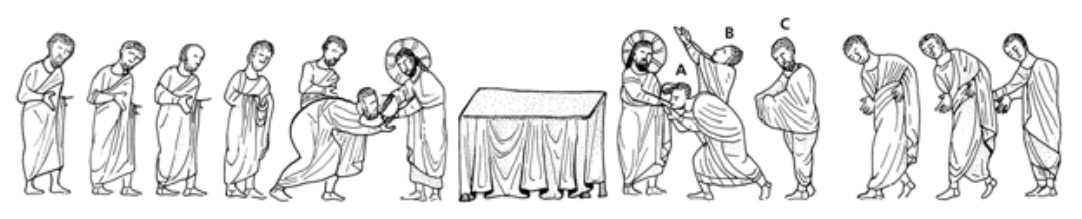

Fig. 7. Reconstruction of the prototype of the Communion of the Apostles according to Loerke [drawing M. Ober, RGZM]. 


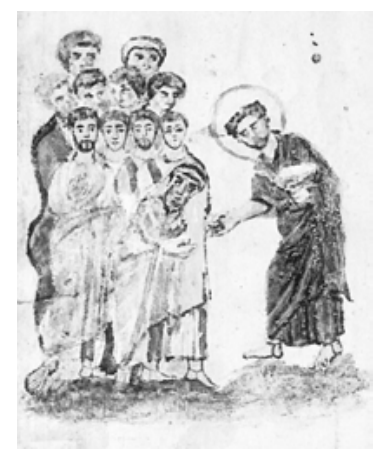

Fig. 8. Rabbula Gospels. Florence, Laurentian Library, Ms. Plut I. 56 fol. 11b, Communion of the Apostles [after C. Cecchelli/G. Furlani/M. Salmi (eds.), The Rabbula Gospels. Facsimile Edition of the Miniatures of the Syriac Manuscripts Plut. I, 56 in the Medicaean-Laurentian Library. Olten/Lausanne 1959].

con or two deacons distributing bread and wine. ${ }^{27}$ This was first suggested by Eduard DOBBERT in $1872^{28}$ and it has been widely accepted. Although there is an abundant bibliography on the Riha paten (and to a lesser extent on its twin piece) this interpretation, which is crucial for the understanding of the iconography, has remained essentially unquestioned. But the assumption that Christ reflects the role of priest and deacon is problematic for one reason: the communion is usually distributed by a priest (bread) and a deacon (wine).$^{29}$ Iconographically, the deacon would be made equal to the priest acting in figura Christi, something which would be rather strange. ${ }^{30}$ The priest is acting in figura Christi

27 T. Frese, Aktual- und Realpräsenz. Das eucharistische Christusbild von der Spätantike bis ins Mittelalter. Neue Frankfurter Forschungen zur Kunst, 13. Berlin 2013, 64; Boyd, Art (as footnote 14 above), 162, 175; G. M. A. HANFMANN, The continuity of classical art: culture, myth, and faith, in K. Weitzmann (ed.), Age of spirituality: a symposium. New York 1980, 90; ScHRADER, Christian sources (as footnote 1 above), 149; LoERKE, Monumental miniature (as footnote 12 above), 79 (Christ, depicted twice to serve as two deacons ...); E. Lucchesi PALLI, Apostelkommunion. Lexikon der christlichen Ikonographie I (1968), 173-176: 174. For this idea see also Sevrugian, Rossano-Codex (as footnote 2 above), note 523 with the addition, that communion was dispensed by a priest and a deacon, and sometimes by two deacons.

28 E. DobBert, Die Darstellung des Abendmahles durch die byzantinische Kunst. Jahrbücher für Kunstwissenschaft 4 (1872), 281-344: 303.

29 S. SAlaville / G. Nowack, Le rôle du diacre dans la liturgie orientale. Etude d'histoire et de liturgie. Archives de l'Orient Chrétien, 3. Paris/Athènes 1962, 78-83.

30 Though e.g. the Didascalia (Didasc. 9) and Ignatius of Antiochia (Ign. Magn. 6,1) compared in the 2nd century allegorically the deacon with Christ (Didascaliae Apostolorum Canonum ecclesiasticorum Traditionis apostolicae versiones latinae. rec. Erik Tidner. Texte und Untersuchungen zur Geschichte der altchristlichen Literatur. 75. V. Reihe, Bd. 19. Berlin 1963, XXV $29 \mathrm{f}$.; Die Briefe des Ignatius von Antiochien, in: Die Apostolischen Väter Übers. und Hrsg. A. Lindemann/H. Paulsen. Tübingen 1992, 194f.), this notion left no traces neither in art nor in theological debates for the period in question. - Essentially the office of the deacon was 
while the deacon is merely assisting. However, angels (in most cases holding rhipidia) appear as deacons in representations of the Communion of the Apostles from the eleventh century on (fig. 3. 13). ${ }^{31}$ This visual differentiation affirms that the heavenly analogy of priest and deacon could be clearly expressed in the iconography of the scene. As there are examples featuring only a single depiction of the Lord after Iconoclasm in Byzantine and "Coptic" art, it is obvious that some other reason must have caused the invention of the twofold depiction of Christ in the context of the Communion of the Apostles. Recently Yannis VARALIS has suggested that the double depiction of Christ behind the altar should be considered as an emphasis on his 'double nature' (the two natures) and his supposed twofold role in the celebration of the Eucharist ${ }^{32}$ without further discussing the significance of the two natures for the understanding of the Riha paten and generally the emergence of the iconography of the Communion of the Apostles. Since images of the Eucharistic ritual in middle and Late Byzantine church decorations, ${ }^{33}$ as well as the sudden appearance of the words of institution on middle Byzantine church vessels, ${ }^{34}$ have been rightly interpreted as advertisements of Orthodox Christological doctrine against heresies, is it possible that we can discern a similar attitude in the early Byzantine period?

In this paper, I discuss the possible Christological significance of the iconography of the Riha paten in its early Byzantine context. More specifically, I investigate its function as a gift by a member of the imperial elite in a specific historical and geographical setting, a point that has not received adequate scholarly attention. Why do all four pre-iconoclastic examples of this rare motive appear in the same region in the sixth century? Is it a coincidence that the Riha paten as well as its twin was donated during the persecution of the Miaphysites

linked to the ministry of the angels. Woodfin, Celestial hierarchies (as footnote 3 above), $310 \mathrm{f}$. - Since the fourteenth century Christ may appear dressed as high priest while angels are char-

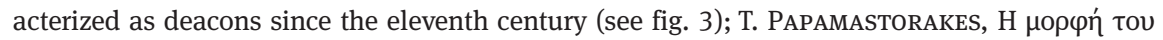

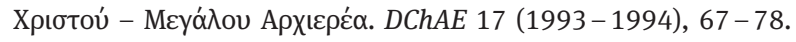

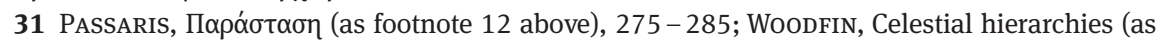
footnote 3 above), 313. - Angles assisting Christ in the distribution of bread and wine appear in the wall painting of the church of St Panteleimon at Nerezi (dated 1164) and some cases of the Late Byzantine period, e.g. in the wall paintings of the monastery of Chilandar on Mount Athos

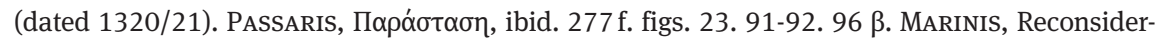
ation (as footnote 12 above), 12 fig. 1.

32 VARALIS, Communion (as footnote 5 above), 50. 61.

33 AsutAy-EFFEnBERger/EFFEnBERger, Byzanz (as footnote 1 above), 218-221 figs. 87-88; GERSTEL (as footnote 12 above), 58-63.

34 S. Albrecht, Zum Auftreten der Einsetzungsworte auf Kelch und Patene seit dem 10. Jahrhundert. Byzantinoslavica 78 (2020), $117-145$. 


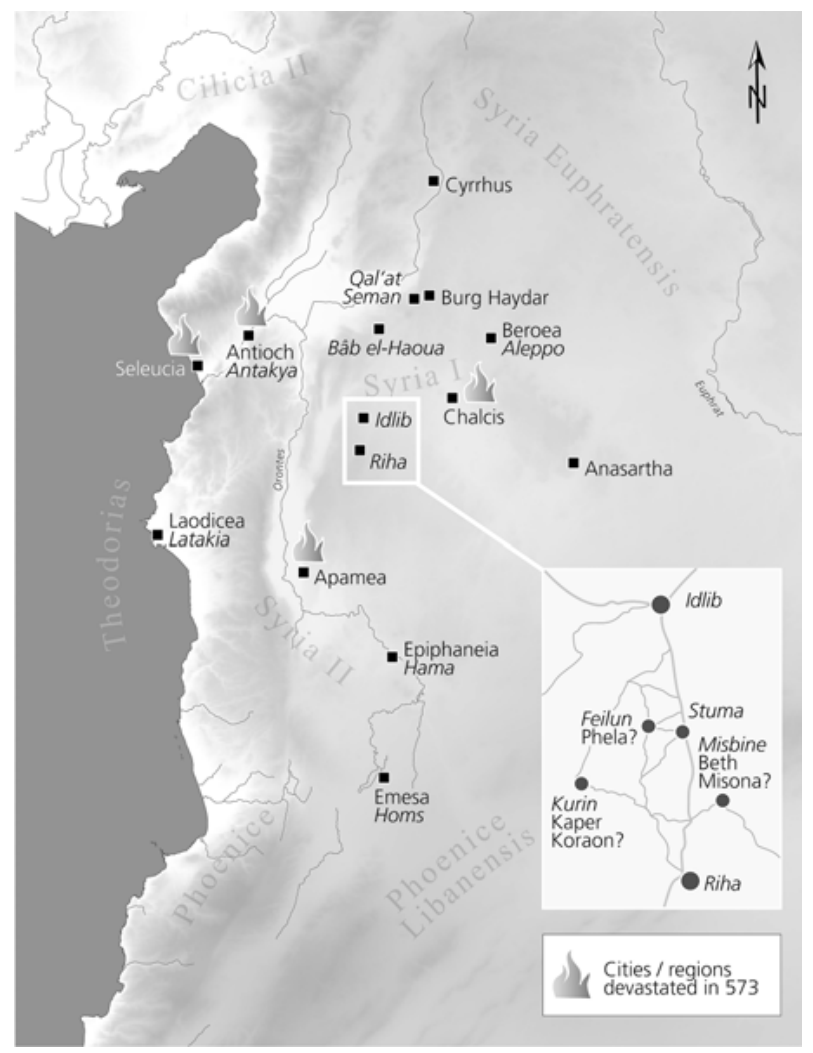

Fig. 9. Map of Syria showing selected major cities and sites referred to in this paper [M. Ober/RGZM].

in the 570s or is the iconography with the twofold depiction of Christ related to imperial church policy, namely, an expression of Chalcedonian doctrine?

\section{The geographical and historical setting}

Although the silver objects of the so-called Riha treasure were not properly excavated, their acquisition history can be traced back to the region of discovery in northern Syria. Of the five objects attributed to the Riha treasure, three are housed at Dumbarton Oaks while the two strainers are part of the collection 
of the Abegg Stiftung at Bern, Switzerland. ${ }^{35}$ The Riha paten was acquired in 1924 in Paris by the founders of Dumbarton Oaks, Mildred and Robert Woods Bliss, from the art dealer George Demotte. Previously it was in possession of the Armenian art dealers Hagop and Garbis Kalebdjian in Paris ${ }^{36}$ and some museums acquired gypsum casts from them. ${ }^{37}$ The original find spot and date of discovery are unknown, but all indications point to a place near the village of Riha in northern Syria which is situated c. $13 \mathrm{~km}$ to the south of Idlib (fig. 9) ${ }^{38}$ T. E. LAWRENCE ("Lawrence of Arabia") asserted that he was present at the discovery of the treasure named after the village Riha and that he acquired the chalice, which was later stolen from him. ${ }^{39}$ Although this is a nice story, it is certainly untrue as the treasure was discovered before his first visit to Syria in the summer of $1909 .^{40}$ A letter dated April 19th 1909 by George MARCoPoLI, an art dealer at

35 On the strainers and their dating to the early years of the reign of emperor Maurice (582602): E. CRUikshank DodD, Byzantine silver stamps: supplement II. DOP 22 (1968), 143 149 nos $31.1-2$.

36 They were active in Paris since 1905 when they opened their antiquities dealership Kalebdjian Frères. https://www.doaks.org/resources/bliss-tyler-correspondence/annotations/ka lebdjian-freres (viewed July 8th 2021).

37 The Gipsabformerei der Staatlichen Museen in Berlin owned a mould since 1914 and still sells copies of the Riha paten: https://www.gipsformerei-katalog.de/sammlungsgebiete/by zanz-und-renaissance/1260/silberplatte-kommunion-der-apostel (viewed July 8th 2021). The Römisch-Germanisches Zentralmuseum at Mainz (RGZM) acquired a gypsum cast of the paten in 1917 (inventory no. 27811) probably from this source. Apparently the cast was made in connection with an extension of the collection of early Christian pieces of the museum as can be deduced from the foreword of W.F. VolBach, Metallarbeiten des christlichen Kultes in der Spätantike und im frühen Mittelalter. Kataloge des Römisch-Germanisches Central-Museums, 9. Mainz 1921. This volume was initiated in connection with the planed extension. The Riha paten is referred to ibid., $17 \mathrm{pl}$. I and in W. F. VoLBACH, Kultgeräte der christlichen Kirche im frühen Mittelalter. Kulturgeschichtliche Wegweiser durch das Römisch-Germanische Central-Museum, 9. Mainz 1925, 11 fig. 4. - In 1985 a new replica was made from the old gypsum cast in galvano technique (RGZM inventory no. 42044).

38 Todt/VEst, Syria (as footnote 25 above), 1650 f. s.v. ar-Rīhā.

39 According to a letter by Royall Tyler to Mildred Barnes Bliss dated February 1st, 1924: https://www.doaks.org/resources/bliss-tyler-correspondence/letters/01feb1924 (viewed July 8th 2021).

40 Already Mundell Mango, Silver (as footnote 1 above), 22 pointed out that this story is to be treated with caution. - On Lawrence's first tour through Palestine, Lebanon and Syria from July 1909 until December 1909 see J. WiLson, Lawrence of Arabia. The authorized Biography of T.E. Lawrence. London 1989, 59-75 esp. 60f. map 1. He passed the region of the supposed finding spot in August 1909. It is not impossible that he spotted the Riha treasure in the gallery of George Marcopoli during his stay at Aleppo. As he bought Hittite seals in villages near the Euphrates in August or September 1909 that were stolen from him (ibid., 61) the reference of Royall Tyler (footnote 39) is probably mixing up things. 
Aleppo, to O.M. DALTon, curator at the British Museum, ${ }^{41}$ refers to the finding spot of the paten as "dans une ruine située dans un champs de labour appurtenant à un village, situé au sud-ouest d'Alep entre Idlib et Riha."42 A journal entry by the British archaeologist Gertrude BELL ${ }^{43}$ dated February 10th 1909 is the earliest proof for the existence of the paten. She was impressed by the piece and its relief decoration, which she saw in the collection of George MARCOPOLI in Aleppo. ${ }^{44}$ BELL's testimony is corroborated by a photograph taken in 1909 which shows the piece uncleaned and heavily corroded. ${ }^{45}$ About the find spot, she notes: "The plate was found in a chapel or coenobium near Kalat Seman together with seven pieces less good which were seized by the government."46 From BELL's journal entry it can be deduced that the Riha paten and the rest of the treasure ${ }^{47}$ were discovered before February 1909 in northern Syria but the information about the find spot near Kalat Seman (fig. 9: Qal'at Seman) is apparently wrong. There are strong indications that the Riha treasure was found simultaneously and most probably in the same spot as the closely related Stuma treasure, which consists of another five silver objects that were confiscated by Ottoman authorities and entered the Archaeological Museum at Istanbul in February 1908. ${ }^{48}$ Both villages Stuma and Riha are located south of Idlib at

41 S. Heid/M. Dennert (eds.), Personenlexikon zur Christlichen Archäologie. Forscher und Persönlichkeiten vom 16. bis zum 21. Jahrhundert. Regensburg 2012, 355 f. s.v. Ormonde Maddock Dalton (M. DENNERT).

42 Mundell Mango, Silver (as footnote 1 above), 21; Ross, Catalogue (as footnote 1 above), 13. Unfortunately the letter preserved in the archives of the British Museum and seen by Ernst Kitzinger in the 1930s was misplaced according to Mundell Mango, Silver (as footnote 1 above), 35 note 3.7 .

43 Heid/Dennert (as footnote 41 above), 148f. s.v. Gertrude Margaret Lowthian Bell (M. DenNERT).

44 Mundell Mango, Silver (as footnote 1 above), 20 f.; Ross, Catalogue (as footnote 1 above), 13.

45 Mundell Mango, Silver (as footnote 1 above), 165 fig. 35.9.

46 Ross, Catalogue (as footnote 1 above), 13.

47 To the Riha treasure five objects are attributed: Mundell MANGo, Silver (as footnote 1 above), $20-24$ nos 30. 32. 35. $37-38$.

48 According to the initial publication by J. EBERSOLt, Le trésor de Stûmâ au Musée de Constantinople. Revue Archéologique 17 (1911), 407 - 419 the treasure was found "dans un champ à Stûmâ, village situé au sud d'Idlib”. On the discovery of the treasures and their relation see also EFFEnBERGER, Bemerkungen (as footnote 9 above), 260; Mundell MANGo, Silver (as footnote 1 above), 20-25; Ross, Catalogue (as footnote 1 above), 13. - On the objects attributed to the Stuma treasure Mundell Mango, Silver (as footnote 1 above), 20 nos 31. 33-34. 36. 39. 
a distance of just six kilometres from each other (fig. 9). ${ }^{49}$ Marlia MundELL MANGo has suggested that the Riha and Stuma treasures, as well as the so-called Hama and Antioch treasures, were all part of a large hoard of church silver of the village of Kaper Koraon (identified as modern Kurin) ${ }^{50}$ at a short distance from Stuma and Riha, but her conclusions were questioned by Arne EFFENBERGER and Gianfranco FiAcCAdoRI. ${ }^{51}$ There is no need to revisit this problem here. For the purposes of this paper, it is sufficient to conclude that the Riha and Stuma treasures were both most likely discovered in the same spot in the region just to the south of Idlib. ${ }^{52}$ It is safe to assume that the Riha and Stuma patens belonged to a church (or to different churches) of a nearby village. This assumption is corroborated by the fact that the donor of the Riha paten Megas was as curator probably in charge of a nearby estate belonging to the imperial domain of Hormisdas (see below). ${ }^{53}$ The patens were likely hidden together with other valuables either as a consequence of the Sasanian campaign in the region in 611 or the rapid Arab attacks in the late 630s. ${ }^{54}$

49 Mundell Mango, Silver (as footnote 1 above), 21 fig. II.1. On the sites of Stuma and Riha see Todt/Vest, Syria (as footnote 25 above), 1514 s.v. al-Mastūma; 1650 f. s.v. ar-Rīhā.

50 On the site see Todt/Vest, Syria (as footnote 25 above), 1361 s.v. Kaprokoraōn, kōmē.

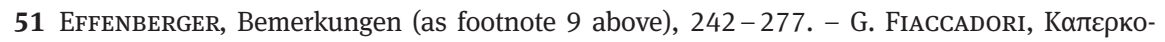
$\rho \alpha \omega v /$ Катрокор $\alpha \omega(v)$. La Parola del Passato 271 (1993), 287-291 has pointed out that the identification of Kaper Koraon with modern Kurin cannot be taken for certain. He suggests

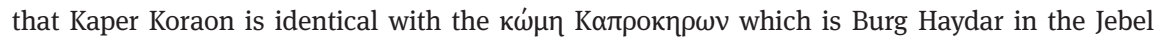
Siman in Syria (fig. 9). On the site see TodT/Vest, Syria (as footnote 25 above), 1359. - For a short review of Mango's thesis see S.R. HAUSER, Treasure: Kaper Koraon. The Eerdmans Encyclopedia of Early Christian Art and Archaeology, 2. Grand Rapids 2017, 630. - G. FowDEn, The babarian plain. Saint Sergius between Rome and Iran. Berkeley 1999, 114 assumes a find spot in the area of Hama.

52 On the common find spot see also the comments by EFFENBERGER, Bemerkungen (as footnote 9 above), 260.

53 On the domains of Hormisdas see Todt/Vest, Syria (as footnote 25 above), 1307 f. s.v. Hormisdou, oikos tōn; G. Tchalenko, Villages antiques de la Syrie du Nord. Le massif du Bélus à l'époque romaine, I. Bibliothèque archéologique et historique, 50. Paris 1953, 114-117. $393 \mathrm{f}$. pl. XL, 2.

54 On the relation between the burial of early Byzantine silver hoards during the Sasanian and Arab invasions see H. HELLENKEMPER, Ecclesiastical silver hoards and their findspots: implications for the treasure found at Korydalla, Lycia, in Boyd/Mundell Mango, Ecclesiastical silver plate (as footnote 7 above), 65-70; EFFENBERGER, Bemerkungen (as footnote 9 above), 264; H. HeLlenkemper, Byzantinischer Schatzbesitz im Arabersturm, in: The $17^{\text {th }}$ International Byzantine Congress, Abstacts of Short Papers. Washington 1986, 141 -142; cf. J. DrauschKe, Bemerkungen zu den Auswirkungen der Perser- und Arabereinfälle des 7. Jahrhunderts in Kleinasien, in O. Heinrich-Tamaska (ed.), Rauben - Plündern - Morden. Nachweis von Zerstörung und kriegerischer Gewalt im archäologischen Befund. Tagungsbeiträge der Arbeitsgemeinschaft Spä- 
The Riha paten was dedicated by Megas and his wife Nonnous. ${ }^{55}$ As attested by the inscription on the two ewers he donated some years after the Riha paten during the reign of Maurice (582-602), Megas held the office of curator of some domus divina and was bestowed with the high court dignities of honorary consul and patrikios: ${ }^{56}$

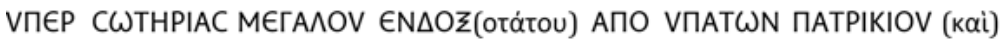 KOVPATOPOC TOV EVCEBECTATOV HMWN $\triangle E C П O T O V$ (Kळi) ANAПAVCEWC

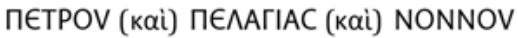

The donor is identified as the curator Megas to whom the Frankish king Childebert II addressed a letter in 587/88. ${ }^{57}$ An almost contemporary inscription discovered near Bâb el-Haoua at some $45 \mathrm{~km}$ from Riha marks the boundary of a village belonging to the domain of Hormisdas and refers to the famous Magnos the Syrian as curator of the domus divina $\tau \tilde{\omega} v^{\circ} \mathrm{O} \rho \mu^{\prime} \sigma \delta \delta$, i.e. the property belonging to the palace of Hormisdas. ${ }^{58}$ Megas likely held the same office some years later. He had donated the Riha paten together with his wife Nonnous but judging

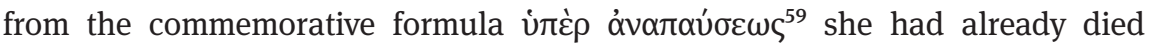
when he donated these ewers. ${ }^{60}$ Nothing is known about his rank in 575/76 when the Riha paten was manufactured. At that time Megas seems to have been involved in the financial administration as can be concluded from the hexagonal stamps on the two silver patens and a silver lamp of the Stuma treasure. ${ }^{61}$

tantike und Frühmittelalter, 6: Zerstörung und Gewalt im archäologischen Befund (Bremen, 5.-6. 10. 2011). Hamburg 2013, 117-159: $140 \mathrm{f}$.

55 CRUiKshank Dodd, Silver treasures (as footnote 14 above), 45.

56 Mundell Mango, Silver (as footnote 1 above), 175-179 nos 37-38; Cruikshank Dodd, Supplement II (as footnote 35 above), 145-149; IDEM, Silver treasures (as footnote 14 above), 7 pls $1-4$.

57 Martindale/Jones/MorRis, Prosopography (as footnote 8 above), 870 f. s.v. Megas 2; FeISSEL, Magnus (as footnote 9 above), 469-472.

58 Todt/Vest, Syria (as footnote 25 above), 1307 s.v. Hormisda, oikos tōn. - On the inscription TCHALENKo, Villages (as footnote 53), $114-117$; JALABERT/MOUTERDE, Inscriptions (as footnote 6 above), $289-290$ no. 528. - For Magnos and his career see W. BRANDEs, Finanzverwaltung in Krisenzeiten. Untersuchung zur byzantinischen Administration im 6.-9. Jahrhundert. Forschungen zur byzantinischen Rechtsgeschichte, 25. Frankfurt 2002, 41 with note 146. 572 f.; MARTINDALE/Jones/MorRIs, Prosopography (as footnote 8 above), $805-807$ s.v. Magnus 2; Delmaire, Les responsables (as footnote 8 above), 278 - 281; FeISSEL, Magnus (as footnote 9 above), 465 476. - On the domain of Hormisdas R. Delmaire, Largesse sacrées et res privata. L'aerarium imperial et son administration du $\mathrm{IV}^{\mathrm{e}}$ au $\mathrm{VI}^{\mathrm{e}}$ siècle. Collection de l'École française de Rome, 121. Paris 1989, $223 \mathrm{f}$.

59 On the formula see WitT, "Hyper Euches" (as footnote 6 above), 188-190.

60 Mundell Mango, Silver (as footnote 1 above), 175.

61 CRuikshank Dodd, Silver stamps (as footnote 8), 108. 114 nos 27 and 29; IDEM, Supplement II (as footnote 35 above), 144 no. 27.1. 
These stamps bear the name M૯ГA^OV and Erica DoDD has concluded that this official is identical with the donor of the Riha paten. ${ }^{62}$ All three vessels were stamped during the years $574-578 .^{63}$ It is safe to assume that Megas, both in his capacity as stamping official ${ }^{64}$ and later as the curator of a domus divina, would have been residing at Constantinople, ${ }^{65}$ although his name might point to an origin from Syria. ${ }^{66}$ Furthermore, DoDD believes that he acquired the stamped Riha paten as well as later the ewers in Constantinople and had them decorated there as a donation for a church in Syria. ${ }^{67}$

Sergios, the donor of the Stuma paten and other pieces of church silver, ${ }^{68}$ was as tribunus and argyroprates also part of the imperial elite. Sergios was probably personally connected to Megas as he might have been the brother of Sergia named in the inscription on the Riha paten. ${ }^{69}$ It remains unclear to which function the title of tribunus - originally a military officer - was related. It has been

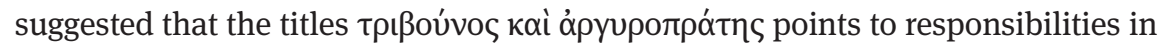
a state silver factory (as tribunus fabricae) ${ }^{70}$ but this is not necessarily the case. A tribunus fabricae is attested only once as being in charge of arms manufactories at Antioch in the mid-fourth century. ${ }^{71}$ The commanders of military units were frequently styled tribunus ${ }^{72}$ but the title was also honorary. In the latter case,

62 CRUIKSHANK DodD, Silver treasures (as footnote 14 above), $45 \mathrm{f}$.

63 For a dating of these objects to the joint reign of Justin II and Tiberius Constantine (as Caesar) see Mundell Mango, Silver (as footnote 1 above), 155 f. $159 \mathrm{f} .171$.

64 CRUIKSHANK DodD, Silver treasures (as footnote 14 above), $46 \mathrm{f}$.

65 On the curators of the domus divinae residing at Constantinople see BRANDES, Finanzverwaltung (as footnote 58 above), $41 \mathrm{f}$. The dignities named in the inscription point to a very high position at court. Therefore he was not a local trustee of imperial property.

66 For testimonies for Megas (Megalos) as a common name in Syria see the compilation by FeIsSEL, Magnus (as footnote 9 above), $469 \mathrm{f}$. note 21.

67 Cruikshank Dodd, Silver treasures (as footnote 14 above), $46 \mathrm{f}$. See also Boyd, Art (as footnote 14 above), $178 \mathrm{f}$.

68 Martindale/Jones/Morris, Prosopography (as footnote 8 above), 1130 s.v. Sergius 11. Sergios also donated a lamp and another paten: Mundell MANGo, Silver (as footnote 1 above), 155-164 nos 33-34; 171-174 no. 36.

69 EFFEnBERger, Bemerkungen (as footnote 9 above), 254f.; Mundell Mango, Silver (as footnote 1 above), 10.

70 Mundell Mango, Silver (as footnote 1 above), 9 f. 160.

71 Ammianus Marcellinus XIV 7,18; 9, 4 (Ammiani Marcellini Rervm gestarvm libri qvi svpersvnt, ed. W. Seyfarth. Leipzig 1978); A.H.M. Jones/J.R. Martindale/ J. Morris, Prosopography of the Later Roman Empire I. Cambridge 1971, 302 s.v. Eusebius 9.

72 R. Grosse, Die Rangordnung der römischen Armee des 4.-6. Jahrhunderts. Klio 15 (1918), 122-161: $148-150$. 
it was combined with other offices with no military function ${ }^{73}$ and this is likely to be the case with Sergios. Possibly Sergios had bought the title of tribunus. ${ }^{74}$ The

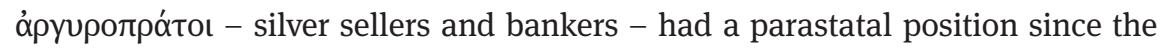
mid-sixth century. Among others, they were involved in the financial administration and transactions of tax payments of large estates either state-owned or private. ${ }^{75}$ They were allowed to enter imperial service and to achieve dignities while still pursuing their business. ${ }^{76}$ By the end of Justinian I's reign ópyvpo$\pi \rho \alpha ́$ тo were often attached to high ranking courtiers and managed their financial affairs. ${ }^{77}$ For example, the banker Markellos, a native of Cilicia, ${ }^{78}$ pursued his business at Constantinople and was active for Aitherios, ${ }^{79}$ the curator of the domus divina Antiochi. ${ }^{80}$ Maybe Sergios had a comparable relationship with Megas or was involved in the administration of the nearby imperial domains of Hormisdas on behalf of its curator Magnos.

Apart from Megas and Sergios, the other donor of the Stuma paten, an excubitor named Theodore, is attested in the 570s in church silver from the region as a high ranking dignitary. ${ }^{81} \mathrm{He}$ donated the paten of the Phela treasure which was stamped in $575 / 76 .{ }^{82}$ The find spot of that treasure is uncertain. A site on the Mediterranean coast of northern Syria and the modern village Feilun west of the vicinity of Stuma (based on a suggested identity of Phela with Feilun) have been suggested. ${ }^{83}$ The presence of the excubitor Theodore ${ }^{84}$ at Phela is explained by

73 GRosse, Rangordnung (as footnote 72 above), 151.

74 On this practice see W. BRANDES, Eine Verschwörung gegen Justinian im Jahr 562 und Johannes Malalas, in L. Carrara / M. Meier/Ch. Radtki-Jansen (eds.), Die Weltchronik des Johannes Malalas. Malalas-Studien, 2. Stuttgart 2017, 357 -392: 364.375 with note 122; BRANDES, Finanzverwaltung (as footnote 58 above), 623 with note 17.

75 BRANDES, Verschwörung (as footnote 74 above), 375; BRANDEs, Finanzverwaltung (as footnote 58 above), 624 .

76 BRANDES, Finanzverwaltung (as footnote 58 above), 623; S.J.B. BARNISH, The wealth of Iulianus argentarius: late antique banking and the mediterranean economy. Byz 55 (1985), 5 - 38: 7.

77 Ibid., 21. 35.

78 Martindale/Jones/Morris, Prosopography (as footnote 8 above), 816 s.v. Marcellus 4. 79 Ibid., 21 f. s.v. Aetherius 2.

80 BRANDES, Verschwörung (as footnote 74 above), $367 \mathrm{f}$.

81 On the status of the excubitores in the sixth century as imperial palace guard and "a small elite of hand-picked men" see J. HALDON, Byzantine praetorians. An administrative, institutional and social survey of the Opsikion and Tagmata, c. 580-900. Poikila Byzantina, 3. Berlin 1984, $136-139$.

82 Mundell Mango, Silver (as footnote 1 above), 233 f. no. 63.

83 Mundell Mango, Silver (as footnote 1 above), 231; Todt/Vest, Syria (as footnote 25 above), 1579 s.v. Phela, kōmē. 
Marlia MUNDELL MANGo in connection with the campaign of Maurice against the Sasanians in 577/578 in which the troops marched through Syria to Mesopotamia. ${ }^{85}$ According to John of Ephesus, many excubitores participated in this campaign. ${ }^{86}$ But as the title was also awarded as an honorary purchasable dignity, at least during the seventh and eighth centuries, ${ }^{87}$ it remains unclear whether the donor of the paten Theodore was in fact an active military officer.

All these donations were made during a long and fierce war with the Persians that lasted from 572 until $591 .^{88}$ The region of northern Syria suffered devastation, plundering and depopulation caused by the Persian campaign in 573 (fig. 9). ${ }^{89}$ But what might have been the intention of Megas to donate such a Eucharistic vessel as the Riha paten in this specific historical situation? MUNDELL

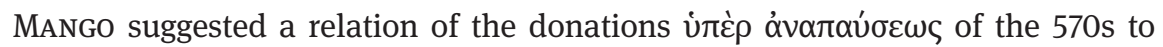
casualties in connection with the Persian invasion of $573 .{ }^{90}$ But since at least some of the donors are likely to have resided in Constantinople, her suggestion remains hypothetical. Rather, such donations to village churches by members of

84 He is possibly identical with the homonymous excubitor named on lead seals of sixth or seventh century date: MARTINDALE/Jones/MorRis, Prosopography (as footnote 8 above), 1265 s.v. Theodorus 7; 1286 s.v. Theodorus 184.

85 The appearance of an excubitor may also be seen in connection with the establishment of additional troops in the oriental provinces after the successive campaign of the Sasanians into Syria in 573. It is assumed that the electi Iustiniani may have been newly based at Gerasa in 576. R. Haensch / A. LichtendBerger/R. Raja, Christen, Juden und Soldaten im Gerasa des 6. Jahrhunderts. Chiron 46 (2016), 177 - 204: 196. On the supposed deployment of troops newly recruited in 574/75 in Greater Syria see also B. FourLAs, Saint Constantine and "the army of heroic men" raised by Tiberius II in 574/575: some thoughts on the historical significance of the early Byzantine Silver hoard at Karlsruhe. Jahrbuch des Römisch-Germanischen Zentralmuseums 62 (2015), $341-375: 348-356$.

86 John of Ephesus, HE 6.14 (ed. E.W. BRooks, Iohannis Ephesini Historiae ecclesiasticae pars tertia. CSCO, 105. Louvain 1935). A connection of the excubitor Theodore with this campaign is suggested by Mundell MANGo, Silver (as footnote 1 above), 234. Maurice marched via Cappadocia and Syria to Mesopotamia. On this campaign see M. WhIтBY, The emperor Maurice and his historian. Theophylact Simocatta on Persian and Balkan Warfare. Oxford 1988, 268-270.

87 HALdon, Praetorians (as footnote 81 above), 154f. 161-164.

88 On the Persian war of AD 572-591 see WhitBy, Emperor Maurice (as footnote 86 above), $195-304$.

89 TodT/VeSt, Syria (as footnote 25 above), 153. Evagr. Schol.V 9-10 (A. HüBNER, Übers., Evagrius Scholasticus, Kirchengeschichte. Fontes Christiani, 57. Turnhout 2007); John of Epiphaneia fragment 5 (C. MüLLER, ed., Fragmenta Historicorum Graecorum IV. Paris 1851, 272 276); John of Ephesus, HE 6.6. - On the impact of this campaign see also F. TROMBLEY, War and society in rural Syria c. 502-613 A.D.: observations on the epigraphy. BMGS 21 (1997), 154-209, esp. $174-178$.

90 Mundell Mango, Silver (as footnote 1 above), 11. 
the imperial elite should be explained by measures to rebuild the region during the three year-truce of $574-577^{91}$ and the following years. The short-term measures taken by the imperial government comprised a tax exemption for the regions devastated by the Sasanian campaign decreed in 575 for which the Caesar Tiberius II Constantine is praised by the Church historian Evagrius Scholasticus. ${ }^{92}$ Is the extraordinary decoration with the scene of the Communion of the Apostles meaningful in this context?

\section{The origin of the Communion of the Apostles}

There is no consensus as to where and when the scene of the Communion of the Apostles was first invented. Some scholars have argued that the scene was initially designed as a monumental composition in church decoration either in Constantinople or Jerusalem. ${ }^{93}$ It is hypothesized that a well-known prototype was mirrored in other media, such as early Byzantine silver patens. The church of the Last Supper on Mount Sion has been assumed as the location of this prototype. ${ }^{94}$ Recently VARALIS has stressed this possibility anew, based on the

91 On this truce see WhitBy, Emperor Maurice (as footnote 86 above), 258f. - On the rebuilding of the region during these years see TROMBLEY, War and society (as footnote 89 above), $185 \mathrm{f}$. 92 Tодт/Vest, Syria (as footnote 25 above), 153; Evagr. Schol. 5.13. - Some inscriptions probably hint to further measures to rebuild the region and to strengthen its military capacities. An inscription from Anasartha (TODT/VEST 832 -834) indicates a rebuilding of its fortification in $578 / 79$ with government funds after a barbarian invasion which is considered to relate to the Persian intrusion of 573. For the dating and interpretation of JALABERT/MOUTERDE, Inscriptions (as footnote 6 above), no. 288 see G.W. Bowersock, Chalcis ad Belum and Anasartha in Byzantine Syria, in: Mélanges Gilbert Dagron. TM 14 (2002), 47 -55. For the few building inscriptions in the region dated to 577/78 as indicator for a recovery see TrombLEY, War and society (as footnote 89), 178. For the deployment of additional troops in Greater Syria and Palestine in these years see footnote 85 above.

93 LoERKe, Rossano Gospels (as footnote 25 above), 136; SCHRADER, Christian sources (as footnote 1 above), 148-150; LoERKE, Monumental miniature (as footnote 12 above), 78-97 esp. 89. - See also S. GerSTEL, Apostolic embraces in communion scenes of Byzantine Macedonia. Cahiers Archéologiques 44 (1996), 141 -148: 142; Сн. Інм, Die Programme der christlichen Apsismalerei. Forschungen zur Kunstgeschichte und christlichen Archäologie, 4. Stuttgart ${ }^{2} 1992$, 68; E. KitzInger, Christian imagery: growth and impact, in Weitzmann, Age (as footnote 27 above), $141-163$ : $153 \mathrm{f}$.

94 LoErke, Rossano Gospels (as footnote 25 above), 136; LoERKE, Monumental miniature (as footnote 12 above), 94. This suggestion was rejected as hypothetical by WEssel, Apostelkommunion (as footnote 12 above), 241 and SCHRADER, Christian sources (as footnote 1 above), $149 \mathrm{f}$.

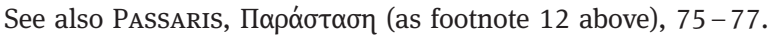


witness of the Armenian pilgrim Movses Dasxuranci of the early seventh century. ${ }^{95}$ Dasxuranci refers to a painted representation of the Last Supper in a chapel attached to the south side of the Basilica of Holy Sion: "On the right side of the church is the upper room of the Sacrament and a wooden cupola on which is painted the Saviour's Last Supper. On its altar, the Sacrifice is offered in the upper storey of Sion (...)." 96 VARALIS suggested that, if one understood the altar as being in the depiction, this account might indicate a representation of the Communion of the Apostles and not the historical Last Supper. ${ }^{97}$ Although this remains possible, the text gives no definite clues about the iconography of the depiction. However, as the last Supper was commemorated at this place, a depiction of the event there is not surprising.

Instead of Jerusalem, some scholars have suggested that the scene of the Communion of the Apostles originated in Constantinople. Their main argument is that the broad reception of the scene in monumental church decoration requires a model in the capital. ${ }^{98}$ Nikolaos Mesarites's Ekphrasis on the Church of the Holy Apostles (written between 1198 and 1203) reports a depiction of the Communion of the Apostles on the soffit of the eastern arch over the altar: "The arch at the east shows us the actual distribution of His own hands of the own Body and Blood of Our Lord and Savior Jesus Christ, which the Savior made as He was going out to His willing and glorious and life-giving death to His blessed table-companions and followers [...] and Christ Himself, the sacrificer and the sacrifice, stands at the table as though at an altar. [...] He sheds his blood into the cup which He holds in front of Himself with His hands. And He gives them to eat of His flesh, first tasting it Himself." "99 August HeISENBERG and others assumed that the mosaics of the Holy Apostles described by Mesarites

95 VARALIS, Communion (as footnote 5 above), $51 \mathrm{f}$.

96 J. WiLKInSON, Jerusalem pilgrims before the Crusades. Warminster 2002, 165.

97 This is also suggested by LoERKE, Rossano Gospels (as footnote 25 above), 136; LOERKE, Monumental miniature (as footnote 12 above), 94.

98 LoERKe, Monumental miniature (as footnote 12 above), 92. Cf. A. Lidov, Byzantine church decoration and the Great Schism of 1054. Byz 68 (1998), 381-405: 384.

99 Translation and text G. DownEy, Nikolaos Mesarites. Description of the Church of the Holy Apostles at Constantinople. Philadelphia 1957, 871. The description is obviously based on a depiction of the "liturgical" Communion of the Apostles. TH. BASEU-BARABAS, Zwischen Wort und Bild: Nikolaos Mesarites und seine Beschreibung des Mosaikschmucks der Apostelkirche in Konstantinopel (Ende 12. Jahrhundert). Dissertationen der Universität Wien, 230. Wien 1992, 156 161; LoERKe, Monumental miniature (as footnote 12 above), 89. 92; A. HeISENBERG, Grabeskirche und Apostelkirche. Zwei Basiliken Konstantins. Zweiter Teil: Die Apostelkirche in Konstantinopel. Leipzig 1908, 175-181. 
were of sixth-century date and completed under Emperor Justin II. ${ }^{100}$ But this suggestion is based on vague historical evidence and most scholars argue with good reason in favour of a post-iconoclastic date for the mosaic decoration of this church. ${ }^{101}$

Since the Communion of the Apostles is not attested in the monumental decoration of Byzantine churches before the tenth century and becomes standard in the sanctuary only from the eleventh century on, ${ }^{102}$ several scholars have argued that there is no secure evidence for any monumental composition of the theme in the early Byzantine period. ${ }^{103}$ However, the 'Coptic' wall paintings in the sanctuaries of churches in Bawit and Wadi Sarga depicting the Communion of the Apostles were until recently not included in this assessment. Although their dating to the seventh or eighth century is insecure, they are quite probably earlier than the earliest Byzantine examples. ${ }^{104}$ Furthermore, monumental wall paint-

100 Ibid., 167 -170; IDEM, Die Zeit des byzantinischen Malers Eulalios. Philologische Wochenschrift 41 (1921), 1024-1032; O. WuLFF, Altchristliche und byzantinische Kunst, II. Die byzantinische Kunst von der ersten Blüte bis zu ihrem Ausgang. Berlin 1914, 434-436. 449; Wessel, Apostelkommunion (as footnote 12 above), $241 \mathrm{f}$. On the debate concerning the painter Eulalios see also B. DASKAS, A literary self-portrait of Nikolaos Mesarites. BMGS 40 (2016), 151-169. 101 The attribution of the mosaics to the reign of Justin II is based on the indistinct information provided by Theophanes for the year 565/66 that the emperor adorned the church of the Holy Apostles (Theophanes, Chronographia, AM 6058, ed. DE BooR). The text makes allusions to church inventories and endowments providing income, not mosaics. - On the problem of the date of the mosaics described by Mesarites and for a review of the debate until the early 1990s see BASEU-BARABAS, Zwischen Wort und Bild (as footnote 99 above), 227 - 232. A.W. EpSTEIN, The rebuilding and decoration of the Holy Apostles in Constantinople. A Reconsideration. GRBS 23 (1982), 79-92 suggested that the scenes from the Gospel in the church were part of a redecoration during the reign of Emperor Basil I (867-886). On indications in the iconography of the Post-Resurrection cycle for a date not before the twelfth century see N. ZARRAS, A gem of artistic ekphrasis: Nicolaos Mesarites' description of the mosaics in the church of the Holy Apostles at Constantinople, in A. Simpson (ed.), Byzantium, 1180-1204: 'the sad quarter of a century'? National Hellenic Research Foundation Institute of Historical Research, Section of Byzantine Research, International Symposium, 22. Athens 2015, 262-281, esp. 275- 277.

102 GERSTEL, Sacred mysteries (as footnote 12 above), 49. - Lidov, Church decoration (as footnote 98 above), 384 assesses the introduction of the Communion of the Apostles as central theme of the altar apse as crucial innovation of the mid-eleventh century by purpose of leaders at the top of the Byzantine hierarchy.

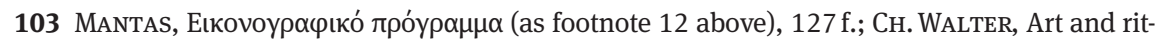
ual of the Byzantine church. Birmingham Byzantine Series, 1. London 1982, 185. - See also the critical comments by SEvrugian, Rossano-Codex (as footnote 2 above), 63.

104 G.J.M. van Loon, The meeting of Abraham and Melchizedek and the Communion of the Apostles, in: M. Immerzeel/J. van der Vliet (eds.), Coptic studies on the threshold of a new millennium, II. Proceedings of the Seventh International Congress of Coptic Studies Leiden, $27 \mathrm{Au}-$ 
ings in the domus Pilati in Jerusalem have been suggested as a prototype for the miniatures of the Rossano Gospels (figs. 5-6), especially those of the Trial. ${ }^{105}$ The splitting of the Communion of the Apostles into two miniatures is explained by the adaptation of a centralized original composition with an altar in the centre (in a cupola or an apse) for the requirements of this book to emphasize the sequence of distribution of wine and bread (fig. 7). ${ }^{106}$ Petra SEvGURIAN has suggested that the scene of the Communion of the Apostles was invented in book illumination in Syria or Palestine. ${ }^{107}$ She states that the miniatures reflect the oldest iconography of the scene and that the composition with the altar on the Riha and Stuma patens is a later addition meant to stress the liturgical context. ${ }^{108}$ Furthermore, she suggests that the decoration of the patens is dependant on an iconographical prototype reflected in the Rossano miniatures ${ }^{109}$ and considers the possibility that the scene was also invented in the region of Syria. ${ }^{110}$

In contrast, Marlia Mundell MANGo has suggested that the silversmiths of the Riha and Stuma patens adopted a symmetrical composition similar to the Rossano miniatures from a single large paten while being forced to put several Apostles "freehand" into a second row. ${ }^{111}$ That patens with figural decoration existed in Constantinople is corroborated by the well-known synodal letter of the three patriarchs to emperor Theophilos (dated 836). In this letter, there is a reference to a paten donated by emperor Theodosios I decorated with "Christ's mystical supper": "Examine and see his sacred offerings, the sacred vestments, and the sacred vessels. Touch and look at the sacred paten, on which is engraved

gust - 2 September 2000. Orientalia Lovaniensia Analecta, 133. Leuven 2004, 1374-1392: $1378-1380.1382$ figs. 8-10.

105 Loerke, Rossano Gospels (as footnote 25 above), 152; W. LoERKe, The miniatures of the trial in the Rossano Gospels. Art Bulletin 43 (1961), 171-195: $184 \mathrm{f}$.

106 LoERKe, Rossano Gospels (as footnote 25 above), 135 f.; LoERKE, Monumental miniature (as footnote 12 above), 79. However, as the miniatures are placed on two contiguous pages they can be perceived as a consistent composition. L. SPECIALE, 'Yлó $\theta \varepsilon \sigma \iota \varsigma$ каvóvoc. Il ciclo evangelico del Codex Purpureus di Rossano: Un'ipotesi di ricostruzione. Rendiconti/Pontificia Accademia Romana di Archeologia 91 (2018-19), 377-431: 395 fig. 9.

107 SEvrugian, Rossano-Codex (as footnote 2 above), 59-64. Her point is supported by WARLAND, Gegenwart (as footnote 17 above), $54 \mathrm{f}$. without further arguments.

108 Sevrugian, Rossano-Codex (as footnote 2 above), 61f. considers the miniatures of the Communion of the Apostles in the Rossano Gospels an "Erstillustration".

109 Sevrugian, Rossano-Codex (as footnote 2 above), 62.

110 Ibid., $63 \mathrm{f}$.

111 Mundell Mango, Silver (as footnote 1 above), 164. 
with encaustic technique ${ }^{112}$ the Last Supper of Christ along with his twelve apostles. With regard to this sacred paten, when Theodore, the treasurer of the Church of the Holy Apostles, was elected to be archbishop of the city of Syracuse he wrote out his profession of faith and placed it upon the said paten. Anthony then said to him, "If you want to convince us that you are of like mind with us, trample on the paten". ${ }^{113}$

In the letter, the narration is used as an example for the veneration of images by the orthodox Emperor Theodosius and the mistreatment of a holy vessel donated by him by an iconoclast bishop. The story does not seem to have been pure fiction. There seems to have existed an old paten with figural decoration depicting either the Last Supper or the Communion of the Apostles in the church of the Holy Apostles at Constantinople. ${ }^{114}$ The attribution to emperor Theodosius I is probably emphasized due to his reception as a pious and orthodox ruler which is useful for the purposes of the text and the mistreatment of the paten is probably a cliché. ${ }^{115}$ But the narration is only credible if such vessels really existed. If the paten was indeed a real object then the name of the donor certainly refers to a commemorative inscription on the vessel itself. ${ }^{116}$ In such a case, em-

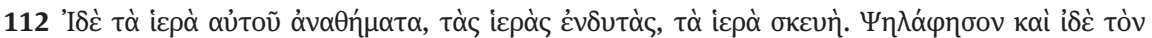

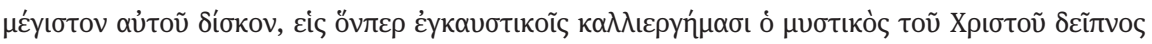

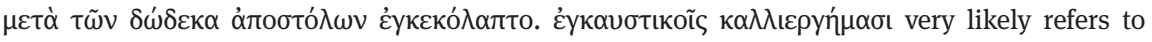
niello decoration. A. BosselmanN, Niello. RbK VI (2005), 965-976. On this term related to niello decoration see also the forthcoming new edition of the Greek treatise 'On the highly appreciated and famous art of the goldsmith' in Codex Parisinus graecus 2327 at the Bibliothèque nationale, which is currently being prepared by a team of the Leibniz-WissenschaftsCampus Byzanz zwischen Orient und Okzident. - P. SPECK, Ich bin's nicht, Kaiser Konstantin ist es gewesen: die Legenden vom Einfluss des Teufels, des Juden und des Moslem auf den Ikonoklasmus. Poikila Byzantina, 10. Bonn 1990, 524 note 1334 proposes that the term refers to mercury gilding (applied as a hot working procedure).

113 Text and English translation in J.A. Munitiz/J. Chrysostomides/E. HarvaliaCRook/CH. Dendrinos (eds.), The letter of the three patriarchs to emperor Theophilos and related texts. Camberley 1997, 64 - 66. - Text and German translation H. GAUER, Texte zum byzantinischen Bilderstreit. Der Synodalbrief der drei Patriarchen des Ostens von 836 und seine Verwandlung in sieben Jahrhunderten. Studien und Texte zur Byzantinistik, 1. Frankfurt 1994, 61. 114 SPECK, Legenden (as footnote 112 above), 476 note 1192 and 524 note 1334 assumes the Communion of the Apostles rather than the Last Supper. - Munitiz/Chrysostomides/HARvALIA-Crook/DEndrinos, Letter (as footnote 113 above), LXIX refer to the Riha and Stuma patens and think that a confusion of the Communion of the Apostles with the Last Supper is plausible. 115 J. Gouillard, Deux figures mal connues du second iconoclasme. Byz 31 (1961), 371 - 401: 396 and esp. 398: "la profanation de la patène est probablement un cliché. Suivant le biographe d'Étienne le Jeune, qui écrit en 808, un évêque avait déjà été dénoncé au concile des Blachernes (754) pour avoir foulé une patène sur laquelle était représentée une déisis.”

116 This is also assumed by SpEck, Legenden (as footnote 112 above), 524 note 1334. 
peror Theodosius $\mathrm{II}^{117}$ as well as the homonymous son of Emperor Maurice, coregent from 590-602, would be the most likely candidates. ${ }^{118}$ If attributed to Theodosius I or the II, it would have rather been decorated with the Last Supper, ${ }^{119}$ if the latter suggestion is accepted a paten with the Communion of the Apostles is possible. Whatever the case, the letter indicates the possibility that church vessels decorated with a scene related to that of the Riha paten existed in Constantinople.

There are indications that the Riha and Stuma patens, as well as the Rossano miniatures, reflect a common iconographic source. Loerke pointed out that the scene was originally designed as a rectangular strip as in the Rossano illuminations for the drum of a dome or the horizontal band of an apse (fig. 7) which had to be adapted to the round shape of the patens. This required a distribution of the apostles in densely packed groups that differed from the model. ${ }^{120}$ Peculiarities like the "misplaced" bowed apostle in front of the altar on the Stuma paten (fig. 2), ${ }^{121}$ as well as the unnaturally elongated legs of the first apostle to the right on the Riha paten (fig. 1) corroborate this hypothesis. Some similarities of the figures like the bowed apostle kissing the hand of Christ (fig. 1. 7: A), the apostle with the raised hands (fig. 2. 7: B), ${ }^{122}$ the apostles receiving wine with their hands veiled (figs. 1-2.7: C), or the related iconography of Christ ${ }^{123}$ further support the hypothesis that the two silver patens and the Rossano miniatures had a common model. Independently from the question in which medium the iconography of the Communion of the Apostles first appeared, the thereinafter broad reception of the scene with the twofold depiction of Christ in Byzan-

117 E. Dobbert, Das Abendmahl Christi in der bildenden Kunst bis gegen des Schluss des 14. Jahrhunderts (3. Fortsetzung). Repertorium für Kunstwissenschaft 14 (1891), 175-203 and 451-463: 182 attributed the vessel to Theodosius II but remarked that this cannot be proven.

118 He was named after Theodosius II. MARTIndALE/JonEs/MorRis, Prosopography (as footnote 8 above), $1293 \mathrm{f}$. s.v. Theodosius 13. - It seems rather unlikely to us that the memory of a holy vessel donated by the usurper Theodosius III reigning from 715-717 (PmbZ \#7793) would had been appreciated that prominent. - It also seems unlikely to us that the passage could refer to the deaf son of emperor Heraclius (MARTINDALE/JonEs/MorRIs, ibid. 1299 s.v. Theodosius 44) or the younger brother of emperor Constans II (PmbZ \#7797).

119 For the appearance of the scene in monumental church decoration of late fourth century Milan see footnote 2 above.

120 LoERKE, Monumental miniature (as footnote 12 above), 81-84. See also Mundell MANGo, Silver (as footnote 1 above), 164 and Sevrugian, Rossano-Codex (as footnote 2 above), 62. 121 LOERKe, Monumental miniature (as footnote 12 above), 83.

122 Ibid., 83.

123 I am referring especially to the head type, the shoulder-length hair, the halo with the inscribed cross with flared ends and the accentuated clavus (on the Riha paten). 
tium definitely points to a long-lasting tradition deeply rooted in the Byzantine realm. In my view, the development of the scene's iconography in Constantinople, as well as the transfer to Syria, is the most likely scenario, especially regarding the Riha and Stuma patens. It can be presumed that the donors Megas and probably also Sergios resided in Constantinople, had easy access to stamped silver objects and presumably also commissioned the inscriptions as well as the figural decoration of the patens in a workshop in the capital. ${ }^{124}$ In light of this, it seems legitimate to raise the question of the specific meaning of the decoration of the Riha paten and its significance in its Syrian context.

\section{The Riha and the Stuma patens: confessions to Chalcedonian faith?}

As mentioned above, VARALIS briefly suggested that the twofold depiction of Christ on the Riha and Stuma patens should be considered as an emphasis on his two natures and his twofold role in the celebration of the Eucharist. ${ }^{125}$ As there are other examples of twofold depictions of Christ in contemporary works of art that most likely express the Chalcedonian doctrine of Christ's two natures this suggestion needs to be taken seriously. The intention to visualize the Chalcedonian formulation has also been suggested for the mosaic in the apse of the church in St. Catherine's monastery on Mount Sinai (565), the mosaics of the sanctuary of the basilica of Euphrasius in Poreč (mid-sixth century), as well as the mosaic programme of the chapel in the Amphitheater at Dyrrachium (most likely dating to the sixth/seventh century). ${ }^{126}$ Something analo-

124 LOERKE, Monumental miniature (as footnote 12 above), 84 assesses the stamps as an additional indication that the prototype for the iconography of the patens was known in Constantinople in the second half of the sixth century. CRUiKshANK DodD, Silver treasures (as footnote 14 above), $44 \mathrm{f}$. suggests that the Stuma paten was executed in Syria on the model of the Riha paten made by a workshop in Constantinople but MundeLl MANGo, Silver (as footnote 1 above), 160 164. $169 \mathrm{f}$. argues for good reasons that both pieces were manufactured, decorated and stamped in the same workshop by two different craftsmen using the same prototype.

125 VARalis, Communion (as footnote 5 above), 50.

126 A. Andreopoulos, The mosaic of the Transfiguration in St. Catherine's Monastery on Mount Sinai: a discussion of its origins. Byz 72 (2002), 9-41: 14 - 18; H. MAGUIRE, Body, clothing, metaphor: the Virgin in early Byzantine art, in L. Brubaker/M. B. Cunningham (eds.), The cult of the Mother of God in Byzantium: texts and images. Birmingham Byzantine and Ottoman Studies, 11. Farnham 2011, 39-52: 42; G. FInGARovA, Mary as intercessor in the decoration of the chapel in Durrës, Albania, in L. M. Peltomaa/A. Külzer/P. Allen (eds.), Presbeia Theotokou. 
gous has been proposed also for the unique double portrayal of Christ in the dome of the small church of Panhagia Drosiani on Naxos (probably the first half of the seventh century), ${ }^{127}$ as well as for the two busts of Christ on the cross donated by the imperial couple Justin II (565-578) and his co-regent Sophia to the Church of Rome. ${ }^{128}$ Nikolaos DRANDAKEs considers both monuments as expressions of the two natures proclaimed by the Council of Chalcedon. ${ }^{129}$ I believe that the emphasis on the two natures of Christ is also the main reason for the twofold depiction of the Lord on the Riha and Stuma patens, as well as in the Rossano Gospels (figs. 1-2. 5-6). The image is not just an artistic solution meant to connect the Last Supper to the Eucharistic ritual. The miniatures of the Rossano Gospel are part of a Passion cycle and combine the pictorial narration of the Last Supper, the Washing of the Feet and the Communion of the Apostles (figs. 4-6) which rarely occur together. ${ }^{130}$ The supplement of the Communion of the Apostles to the image of the Last Supper, as well as the abbreviated Gospel accounts written above the miniatures, indicate that these images were designed as a depiction of the historical institution of the Eucharist. ${ }^{131}$

Sevrugian assumed that the miniatures in the Rossano Gospels (as well as the Sinope fragments) were meant to underscore the human nature of Christ

The intercessory role of Mary across times and places in Byzantium (4th-9th Century). Vienna 2015, 203-218: 209f.

127 N. Drandakis, Panagia Drosiani, in M. Chatzidakis et al., Naxos. Byzantine art in Greece,

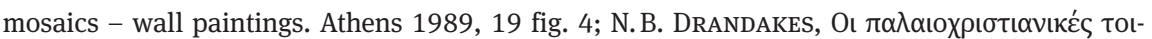

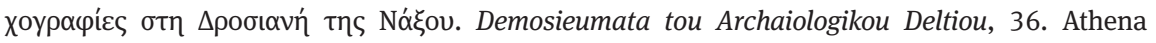
1988, $51-56$ pl. I $\alpha-y$. - On the dating of the paintings ibid., 87-89.

128 On the cross see S. Guido, The Crux Vaticana or the Cross of Justin II - new date and technical remarks resulting from its restoration. Archivum Sancti Petri, Quaderno d'archivio 4-5 (2013), 12 -33; J. SPIER (ed.), Picturing the Bible. The earliest Christian art. Fort Worth 2007, 283-285 no. 83; A. MCClANAN, Representations of early Byzantine empresses. Image and empire. New York 2002, 163-168 (all with preceding bibliography).

129 Drandakes, $\Delta$ poøıaví (as footnote 127 above), 54-56. - He is followed by N. GKioles,

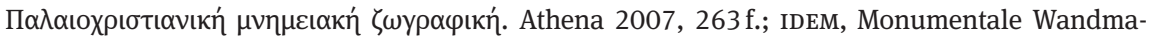
lereien frühchristlicher Zeit in Griechenland, in G. Koch (ed.), Byzantinische Malerei. Bildprogramme-Ikonographie-Stil. Symposion in Marburg vom 25.-29.6.1997.

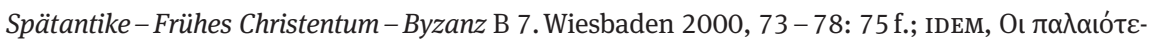

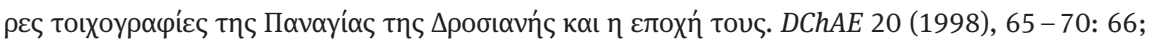

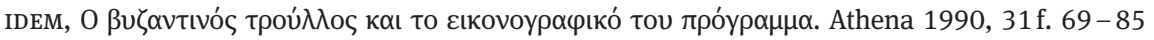
fig. 1 who relates the pictorial programme of the church and especially the two bust images of Christ in the dome to the monoenergetic/monothelite controversy of the 7 th century. - B. SCHELLEWALD, Kuppelbilder. RbK V (1995), 573-620: 589 disagrees with Gkioles' interpretation and suggests that the two images of Christ symbolize the Lord's eternal rulership.

130 Sevrugian, Rossano-Codex (as footnote 2 above), 57-65.

131 This aspect is emphasized by MARINIS, Reconsideration (as footnote 12 above), 7. 


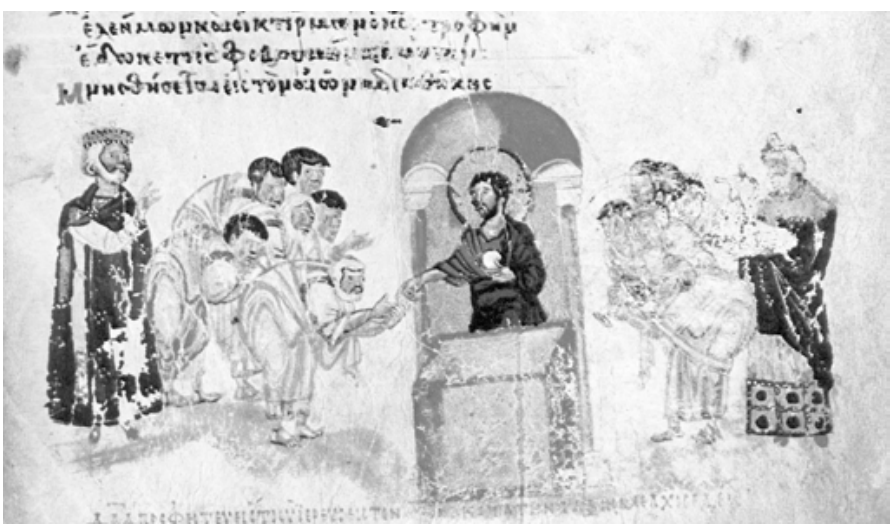

Fig. 10. Chlodov Psalter. Communion of the Apostles. Moscow, Historical Museum MS gr. 129d fol. 115r, Communion of the Apostles [after M. V. ŠčEPKINA, Miniatjury Chludovskoj psaltyri. Grečeskij illjustrirovannyj kodeks IX. veka. Moskau 1977].

(i.e., the Chalcedonian position) ${ }^{132}$ against heresies without giving special reference to the Communion of the Apostles. The idea that especially the iconography of the Communion of the Apostles was initially meant to express and promote Chalcedonian faith is only reasonable as the Eucharist and its appreciation became highly important in the Christological controversies in the fifth and sixth centuries. ${ }^{133}$ Chalcedonians and Miaphysites alike combined their Christology with Eucharistic doctrine. The Chalcedonians understood the bread as the body of Christ in hypostatic union with God $^{134}$ thus stressing the two natures. Contrariwise, Miaphysite theologians emphasized the one divine nature of God that superimposed his human nature by the phrases related to the Eucharist. They refused the formula "body of Christ" and favoured such as "body of the God-Logos" or "body of Christ the God-Logos". ${ }^{135}$ Miaphysite theologians like Severus of Antioch used the formula "body and blood of the crucified and resurrected" to express their Christology. ${ }^{136}$ It is this crucial aspect that distin-

132 Sevrugian, Rossano Codex (as footnote 2 above), 128.

133 V. Menze, The power of the Eucharist in early Medieval Syria. Grant for salvation or magical medication?, in B. Bitton-Ashkelony/ D. Krueger (eds.), Prayer and worship in Eastern Christianities, 5th to 11th centuries. London 2017, 116-131: 117.

134 J. BETz, Eucharistie in der Schrift und Patristik. Handbuch der Dogmengeschichte, 4. Freiburg 1979, $132-141$.

135 Ibid., 128.

136 Ibid., 128. 130; W. DE VRIES, Sakramententheologie bei den syrischen Monophysiten. Orientalia Christiana Analecta, 125. Rom 1940, 140-144. 
guishes the iconography of the miniature in the Gospel of Rabbula (fig. 8) from the images on the Riha and Stuma patens as well as in the Rossano Gospels. Christ is distributing oblations to eleven apostles while grasping a yellowish bowl-shaped vessel with his left hand. ${ }^{137}$ Obviously, Judas is missing. ${ }^{138}$ If the number of eleven apostles is intentional, and I do believe that this is the case, it may indicate that the image is related to the meeting of the resurrected Christ with the dining apostles according to Marc 16,14. But the distribution of bread by Christ to eleven apostles does not refer to any passage of the Gospels. Thus, as all scholars agree, the image cannot be anything else than a "liturgical" reference to the Last Supper alike to the miniatures of the Rossano Gospels. But the eleven apostles together with the single figure of the Lord would then put emphasis on Christ's divine nature which would be a suitable iconographic solution to express the Miaphysite formula "body (and blood) of the crucified and resurrected". The metalepsis is omitted, perhaps due to an influence by Tatian's Diatessaron as Vasiliki TSAMAKDA has suggested. ${ }^{139}$ Klaus WESSEL considered the image an alternative "narrative" type for the Communion of the Apostles bound to book illumination and refers to the examples of the scene in the marginal psalters that first appear in the ninth century where the Lord is in most cases only depicted once (fig. 10). ${ }^{140}$ Here the context in which these images appear is important. They are not set in a sanctuary in which the Eucharistic rite takes place or is placed on a church plate used in the rite but are illustrations of individual psalm verses that are related to the Eucharist. Christ is standing behind an altar and distributes bread to the first apostle approaching from the left while the first apostle on the right side is drinking by himself wine from a cha-

137 Florence, Bibliotheca Medicea-Laurenziana, Ms. Plut I. 56 fol. 11b. C. CeccheLLI, The iconography of the Laurentiana Syriac Gospels, in C. Cecchelli / G. Furlani / M. Salmi (eds.), The Rabbula Gospels. Facsimile edition of the miniatures of the Syriac manuscripts Plut. I, 56 in the Medicaean-Laurentian Library. Olten/Lausanne 1959, 65 and V. TsAmAKDA, Der Einfluss von Tatians Diatessaron auf die frühe Evangelienillustration, in I. Eichner/V. Tsamakda (eds.), Syrien und seine Nachbarn von der Spätantike bis in die islamische Zeit. Spätantike - Frühes Christentum - Byzanz B, 25. Wiesbaden 2009, 167-195: 187 point out that the vessel is a pyx and not a chalice as often assumed.

138 WeSSEL, Apostelkommunion (as footnote 12 above).

139 TsAmaKda (as footnote 137 above), $187 \mathrm{f}$.

140 WESSEL, Apostelkommunion (as footnote 12 above), 241; IDEM, Abendmahl (as footnote 2

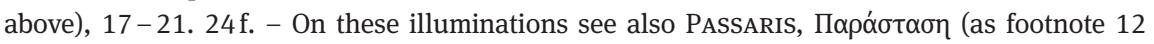
above), 168-173 figs. 158-163. Images alike to the Communion of the Apostles were Christ has his right arm raised are hinting to the blessing of the bread before the Eucharist: ibid., 214-218 figs. 161. 165; AsUTAY-EFFEnBERGER/EFFENBERGER, Byzanz (as footnote 1 above), 220 fig. 88. 
lice. The scene is flanked by David and Melchisedek. These images are obviously newly created for the psalters in the ninth century ${ }^{141}$ and follow a different logic as they are related to the typological interpretation of Psalm 110,4 ("Thou art a priest forever after the order of Melchisedek"). ${ }^{142}$ Images combining Old Testament prefigurations of Christ and their fulfilment in the image of the Incarnated Logos were used by the iconophiles in their visual polemics against the iconoclasts. ${ }^{143}$ As the illuminators of the marginal psalters revised the pattern of the Communion of the Apostles to their purpose they conveyed an entirely different message where a second figure of the Lord distributing wine was not essentially required in this new context.

The image of the Rabbula Gospels is set side by side with other images from Christ's life that have been probably taken from existing models such as monumental picture cycles in churches. ${ }^{144}$ These images were placed in a roughly chronological order besides the canon tables. Massimo Bernabò points out that "the pictorial narratives accompanying the canon tables do not indicate an artist with a sophisticated viewpoint" and furthermore asserts that the relation of the subjects depicted to the passages signalled by numbers in the tables is casual. ${ }^{145}$ This is also the case with the image of the Communion of the Apostles that is not linked to the tenth canon of Mark in the table on fol. 11b. Thus, if a specific Miaphysite Christological understanding is expressed by the image in the Rabbula Gospels (fig. 8) this would have probably been drawn from the

141 For the ad hoc creation of many Psalter illustrations G. R. PARPulov, Psalters and Books of Hours (Horologia), in V. Tsamakda, A Companion to Byzantine illustrated manuscripts. Brill's Companions to the Byzantine World, 2. Leiden 2017, 300-309: $305 \mathrm{f}$.

142 LOERKE, Monumental miniature (as footnote 12 above), 84; WesSEL, Abendmahl (as footnote 2 above), 25. See also MARINIs, Reconsideration (as footnote 12 above).

143 For the sources for the illustration and their iconophile overtones see $\mathrm{CH}$. STEPHAN-KaISSIS, Die Illustrationen der byzantinischen Randpsalterien. Der Chludovpsalter und seine Verwandten. Libri Pretiosi 20 (2017), 43 - 76: 46 - 48; M. EvANGELATou, Liturgy and the illustration of the ninth-century marginal Psalters. DOP 63 (2009), 59-116: 60 f.; EADEM, The illustration of the ninth-century Byzantine Psalters: layers of meaning and their sources. $\mathrm{PhD}$ thesis, Univ. of London, Courtauld Institute of Art, 2002, 203 - 205. LOERKE, Monumental miniature (as footnote 12 above), 84-92 figs. 16-20 pointed out that the representation of the Communion of the Apostles in the marginal psalters were intended to put emphasis on the words of institution in order to refute "one of the major contentions of the Iconoclasts, i.e., that the only symbols Christ gave of his body were the Bread and the Wine.” (p. 92). K. CoRRIGAN, Visual polemics in the ninthcentury Byzantine Psalters. Cambridge 1992, 57. 90 interprets the images as a visual expression intended as a defense of the sacrament of the Eucharist that may have been targeted Muslims. 144 Bernabò, Miniatures (as footnote 25 above), 353; Mundell Mango, Rabbula Gospels (as footnote 25 above), 124.

145 BERnABò, Miniatures (as footnote 25 above), 353. 


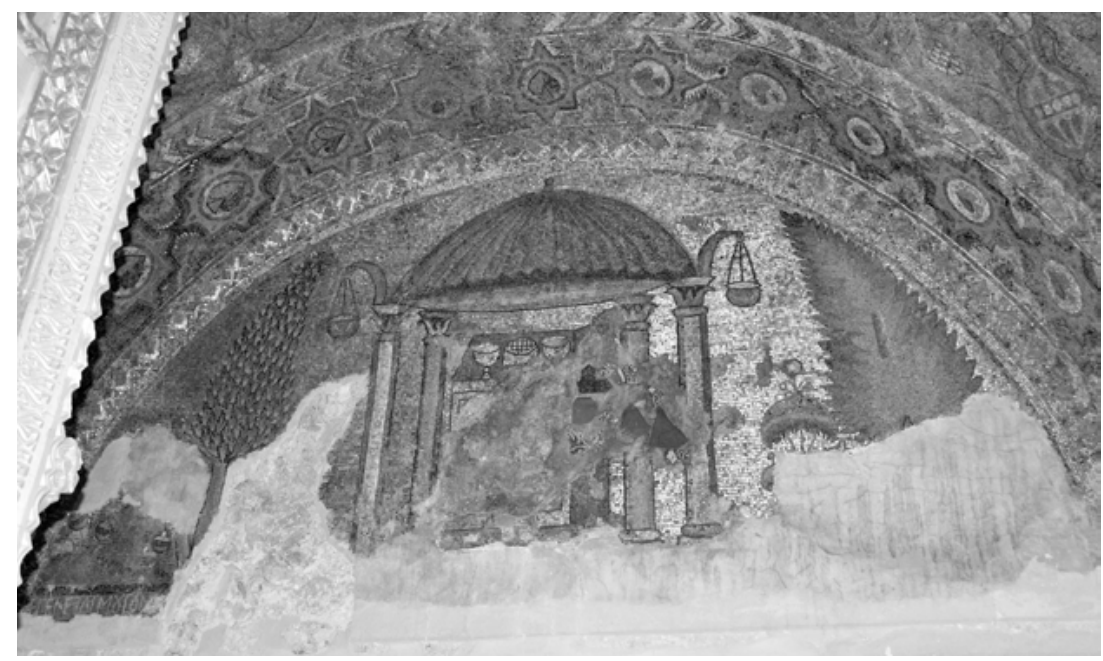

Fig. 11. Monastery of Mār Gabriel at Kartmin, mosaic on the east wall [photo A. Eastmond].

model. The dedicatory illumination ${ }^{146}$ attests that the miniatures were commissioned by monks, thus by patrons for whom we can expect a special awareness of Christological debates.

Images of the Eucharist in a liturgical context that can be associated with Miaphysites are very few. At the monastery of Mār Gabriel at Kartmin, an important centre of Miaphysitism, two mosaics are preserved on the north and south walls of the sanctuary of the church. They are dated to 512 and depict an altar with a ciborium while on the better-preserved panel a paten and two chalices can be seen (fig. 11). ${ }^{147}$ Although these mosaics are related to the Eucharist, they differ fundamentally from the scene of the Communion of the Apostles in their aniconic character. The omittance of figures is thought to be related to the repudiation of the portrayal in corporeal form of incorporeal beings such as Christ in his divinity and angels by the Miaphysite bishop Philoxenus of

146 M. BERnABò, Miniature e decorazione, in M. Bernabò (ed.), Il tetravangelo di Rabbula. Firenze, Biblioteca medicea Laurenziana, Plut. 1.56. l'illustrazione del Nuovo Testamento nella Siria del VI secolo. Folia Picta 1. Roma 2008, 79-112: 110 f. pl. 27; Florence, Bibliotheca MediceaLaurenziana, Ms. Plut I. 56 fol. 14a. CEccheLLI, Iconography (as footnote 137 above), 72. 78. 147 E.J.W. Hawkins / M.C. MundelL, The mosaics of the Monastery of Mār Samuel, Mār Simeon and Mār Gabriel near Kartmin. DOP 27 (1973), 279-296: 289-291 figs. A. 33-35. 
Mabbug. ${ }^{148}$ Thus this monument does not explicitly relate to the question raised here. But a further indication for a potentially Miaphysite conception of the Eucharist of the image in the Rabbula Gospel can be drawn from the four examples of the scene from Egypt, where Miaphysitism was predominant: all of them depict the Lord once standing behind an altar while distributing wine to the apostles. ${ }^{149}$ Especially important is the wall painting from the east wall of an altar room of the south church at Bāwit in the Monastery of Apa Apollo due to its supposedly early date (probably seventh or eighth century). ${ }^{150}$ Since the twofold depiction prevailed in Byzantine monumental depictions in church sanctuaries, this disparity is conspicuous.

For these reasons, it seems possible that the iconography of the Communion of the Apostles especially in a liturgical context may have had primarily a Christological meaning. Thus, in the three images of the Communion of the Apostles of the early Byzantine period, the twofold depiction of Christ should be understood as an expression of Chalcedonian faith. As the Eucharist was a foundational element of the Church in a spiritual sense, both Chalcedonian and Miaphysite bishops in Syria took the matter of the Eucharist seriously. ${ }^{151}$ Volker MENzE has underscored that it was important for the faithful, especially in sixth-century Syria, to be able to "identify a loaf as Eucharistic bread and also to be able to tell if it was "orthodox" Eucharistic bread or that of another Christian party" ${ }^{152}$ This could be achieved by marking or stamping the bread itself. ${ }^{153}$ But the decoration of the Communion of the Apostles on the Riha and Stuma patens would also serve this need as they mark the oblation prepared on this vessel clearly as Chalcedonian.

148 L. JAMES, Mosaics in the medieval world. From late antiquity to the fifteenth century. Cambridge 2017, 219; Hawkins/ Mundell, Mosaics (as footnote 147 above), 294.

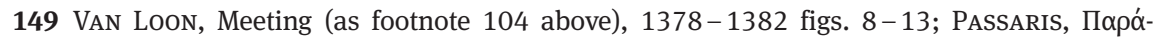

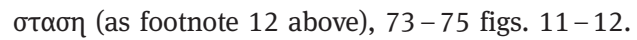

150 VAN Loon, ibid. 1378 figs. 8-9; PASSARIS, ibid. 73 fig. 11.

151 V. Menze, Justinian and the making of the Syrian Orthodox Church. Oxford Early Christian Studies. Oxford 2008, 145 f. 158-165 referring especially to the 520s and 530s.

152 Menze, Eucharist (as footnote 133 above), 118. - J. TAnnous, The making of the medieval Middle East. Religion, society, and simple believers. Princeton 2018, 106-108 has pointed out that the Christological controversies over the Eucharist do not seem to have been of significance to many of the mostly illiterate "simple believers" in the early Byzantine Near East but were of great importance for some members of the clergy, monks and theologians.

153 Menze, Eucharist (as footnote 133 above), 118-122. On Eucharistic bread stamps see G. GALAVARIs, Bread and liturgy. The symbolism of early Christian and Byzantine bread stamps. Madison 1970, esp. 94-98 on examples from Syria. 
In my view, it is remarkable and probably not a coincidence that the Riha and Stuma patens were manufactured and donated at a time when the debate between imperial Chalcedonian "orthodoxy" in contrast to the Miaphysite Christology was highly topical. The religious policies of the early years of Justin II were marked by efforts towards conciliation with Miaphysitism. ${ }^{154}$ When the attempt to settle the dispute finally failed after the Synod of Callinicum in 571, ${ }^{155}$ the imperial government turned to vigorous persecution. On March 21st 571 a severe persecution of the Miaphysites started in Constantinople. It was ended by Tiberius II in 578 but lasted until 580 in Syria. ${ }^{156}$ Miaphysite bishops were forced to receive Chalcedonian communion before the public at the Hagia Sophia. ${ }^{157}$ The patriarch of Constantinople John III Scholasticus, ${ }^{158}$ who originated from Sarmin, a village situated c. $18 \mathrm{~km}$ to the northeast of Riha, sent letters to the provinces, by which ecclesiastical and secular authorities were requested to take measures against the Miaphysites. ${ }^{159}$ It is conceivable that in the context of this persecution new anti-Miaphysite or rather pro-Chalcedonian iconographical motives were invented. ${ }^{160}$ As the Miaphysites were accused of intermixing

154 A. Grillmeier, Jesus der Christus im Glauben der Kirche, 2/2. Freiburg 1989, 503 - 511; A. CAmERon, The early religious policies of Justin II, in D. Baker (ed.), The Orthodox Churches and the West. Studies in Church History, 13. Oxford 1976, 51-67 = A. CAmeron, Continuity and change in sixth-century Byzantium. London 1981, X.

155 Todt/Vest, Syria (as footnote 25 above), $325 \mathrm{f}$.

156 John of Ephesus, HE 1.5; TodT/Vest, Syria (as footnote 25 above), 325. See also W.H.C. FREND, The rise of the Monophysite movement. Cambridge 1972, 321-323.

157 Cameron, Religious policies (as footnote 154 above), 64. - Michael the Syrian, Chronicon 10:3 (J.-B. Снавот, ed., Chronique de Michel le Syrien, Patriarche Jacobite d'Antioche [11661199]. Bruxelles 1963, 295).

158 D.V. ZajCEV/K. A. MAKsimovič, Иоанн Схоластик. Pravoslavnaja enciklopedija, 23. Moskva $2015,478-481$.

159 John of Ephesus, HE 1:5 (John's origin from Sarmin); 2:17 (persecution in the provinces); Todt/Vest, Syria (as footnote 25 above), 325. On Sarmin see ibid., $1722-1725$ s.v. Sērēmis. 160 C. MANGo, The Chalkoprateia annunciation and the pre-eternal logos. DChAE 17 (19931994), 165-170: 168 suggested with caution that the establishment of the iconography of the Theotokos Blachernitissa type during the reign of Justin II might have been intended as an anti-Miaphysite emphasis of the two natures. - On images as a mean to express the adherence of Christological doctrine during the Monothelite controversy in the 7 th century see B. FouRLAS, Zwei Bischöfe, ein Diakon und ein Presbyter. Überlegungen zu einem Mosaikpanel des 7. Jhs. in der Demetrios-Basilika in Thessaloniki, in V. Tsamakda/N. Zimmermann (eds.), Privatporträt. Die Darstellung realer Personen in der spätantiken und byzantinischen Kunst. Akten des Internationalen Workshops an der Österreichischen Akademie der Wissenschaften 14.-15. Februar 2013. Österreichische Akademie der Wissenschaften, Philosophisch-Historische Klasse Denkschriften, 522 = Archäologische Forschungen 30. Wien 2020, 147-190: $173 \mathrm{f}$. 
the two natures of Christ, a visual emphasis of the distinction of the natures by a twofold depiction of the Lord seems to be an obvious solution.

We can only speculate that it would be plausible to explain the donations of the Riha and Stuma patens as being part of such measures against the Miaphysites or, more precisely, a means to promote and strengthen Chalcedonian faith in Syria during these years. The initial cause may have been the looting of the region by the Sasanians in 573 that required the refurbishing of local churches with Eucharistic vessels. This opened up the possibility for members of the elite in Constantinople with contacts to or origin in the region to display their wealth, piety and philanthropy by making donations of the very best silver plate available in the capital something that elevated their social prestige. ${ }^{161}$ But the intention of the distribution of vessels decorated with the Communion of the Apostles may just as much have been an ostentatious act meant to promote Chalcedonian faith in a region with strong Miaphysite opposition. Notably, for Stuma a Miaphysite monastery is attested in 567/569. ${ }^{162}$ For another Miaphysite monastery at Beth Zagba, where the text of the Rabbula Gospels was created in $586,{ }^{163}$ sites just a few kilometres south of Riha have been suggested. ${ }^{164}$ Although the donors Megas and Sergios, who were as imperial dignitaries and undoubtedly Chalcedonians, ${ }^{165}$ may have been acting on a private initiative, they were promoting imperial church policy on behalf of the emperor. In this way, they strengthened the ties of the local community with the imperial government. ${ }^{166}$ Such an act can be considered an open demonstration of the loyalty of the donors to the emperor which was in the end without any doubt favourable for their careers.

161 On the possible significance for the social prestige of the donors see Boyd, Art (as footnote 14 above), 179.

162 Todt/Vest, Syria (as footnote 25 above), 1514 s.v. al-Mastūma. On further Miaphysite monasteries in the Djebel Riha see also Mundell MANGo, Beth Zagba (as footnote 25 above), 416 419 Map 2.

163 On the date see footnote 25 above.

164 Mundell Mango, Beth Zagba (as footnote 25 above), $420 \mathrm{f}$. Map 2.

165 Mundell Mango, Silver (as footnote 1 above), 7.

166 For the role of the local church as forum for expressing loyalty to the imperial government in general, see M. McCormick, Eternal victory. Triumphal rulership in late antiquity, Byzantium, and the early medieval West. Paris 1986, $237 \mathrm{f}$. - On the political role of imperial patronage for Chalcedonian and Miaphysite churches and monasteries in Mesopotamia see E. KeSER KAYAALP, Patronage of churches in the late antique northern Mesopotamia, AD. 300-800, in C. Katipoğlu/E. Yavuz/B. Tabibi (eds.), Mekânlar/Zamanlar/Insanlar: Hamilik ve Mimarlik Tarihi = Spaces/Times/Peoples: Patronage and Architectural History. Ankara 2016, 43-56: 44-48. 


\section{Conclusion}

The liturgical reference and the understanding of Christ as a celebrant is, at first sight, the most distinguished feature of the decoration of the Riha and Stuma patens. However, as I propose in this paper, initially the scene could have been designed primarily as an expression of Chalcedonian dogma directed against the Miaphysites. The iconography with the twofold depiction of Christ was probably newly invented during the last years of Justinian or the reign of Justin II to emphasize the distinction of the two natures as the Miaphysites were accused of intermixing the two natures of Christ. Thus, the exceptional appearance of the scene on the two early Byzantine silver patens from Constantinople in northern Syria can probably be explained by its Christological significance regarding the Chalcedonian doctrine of the Eucharist in the specific historical situation of the 570 s and can be connected to measures to promote Chalcedonian faith in that region. Furthermore, one may hypothesize that the illumination in the Rabbula Gospels (fig. 8) represents a Miaphysite position of the understanding of the Eucharist. If so, the iconographic solution of the Rabbula miniature may have been designed as a reaction to the Christological meaning of the Chalcedonian model represented by the silver patens and the Rossano Gospels (figs. 1-2. 5-6). Be that as it may, I argue that the appearance of the iconography of the Communion of the Apostles in the second half of the sixth century was a response to the debate over Orthodox Christological doctrine at that time. In this way, the newly invented images fulfilled a similar function as has been suggested in the cases of the words of institution on middle Byzantine church vessels and some middle and Late Byzantine images of the Eucharistic ritual, ${ }^{167}$ namely to express and affirm Orthodox identity in opposition to contemporary "heretical" schools of thought.

\section{Appendix: Silver plates depicting the Communion of the Apostles likely to be forgeries}

Two reputed early Byzantine pieces of silverware in the Menil Collection at Houston and the James Farrell 'Collection' at Kansas are likewise decorated with the Communion of the Apostles and have to be briefly discussed in this context.

167 See footnote 33 and 34 above. 


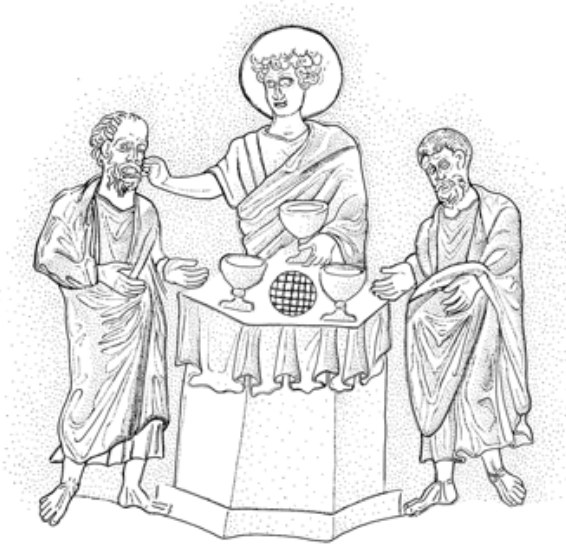

Fig. 12. Motive on the paten in the Menil collection [drawing M. Ober, RGZM after Sotheby's [London], Icons, Russian Pictures and Works of Art, 30th November 1990, 433].

The fragmentary piece at Houston (dated tentatively to ca. 600) was acquired from Sotheby's in 1990 and is of unknown provenance (fig. 12). ${ }^{168}$ It shows Christ behind an altar flanked by Peter and Paul, an abbreviated variant of the scene of the Communion of the Apostles that is rarely attested after iconoclasm, not in early Byzantine art. ${ }^{169}$ The iconography of the plate is obviously a pasticcio of well-known compositions: The heads of the apostles "repeat almost exactly" the busts of Peter and Paul on the famous Emesa vase in the Louvre since

168 Inventory no. 1990-12 DJ. Sotheby's (London), Icons, Russian Pictures and Works of Art, 30th November 1990, 186-189 no. 433. - The piece has not yet been published thoroughly. For a short discussion see D. H. WRIGHT, The Menil paten, in: Twenty-Fifth Annual Byzantine Conference. Abstract of Papers. Washington 1999, $87 \mathrm{f}$. He is accepting the authenticity of the piece and suggests a date in the 620s. - For a brief reference and an image see C. ELLIotT, A history of the Menil Collection, in A. Weyl Carr (ed.), Imprinting the divine. Byzantine and Russian icons from the Menil Collection. Houston 2011, 13 fig. 6. A short entry appears in: The Menil Collection, a selection from the paleolithic to the modern era. Newly Updated Edition. New York 1997, 72 f. no. 62 with a suggested dating to the fourth/fifth century. The piece is illustrated in G. PeErs (ed.), Byzantine things in the world. Houston 2013, 172 ("Byzantine, ca. 600 CE”), without further mentioning in the text.

169 Athens, National Library, cod. 211, fol. 110v: Galavaris, Bread and liturgy (as footnote 153 above), 178 fig. 95; Codex Purpureus (Munich, Bayerische Staatsbibliothek MS lat. 23631, fol. 48v). On this cf. E. Thunø, Image and relic. Mediating the sacred in early medieval Rome. Analecta Romana Instituti Danici, Supplementum, 32. Rome 2002, 81 an. 217 with further examples. 
1892. ${ }^{170}$ The composition of the grid-stamped loaf of bread flanked by a chalice on each side is obviously adopted from the wall mosaic at the church of the Monastery at Mār Gabriel at Kartmin, published in 1973 (fig. 11). ${ }^{171}$ But on the Menil paten, the bread is presented in bird's view from above in sharp contrast to the chalices which are depicted in oblique view. On the old photograph of the mosaic at Kartmin (fig. 11), one might have the impression that the loaf is lying directly on the altar as on the Menil paten. But from images published more recently, it is evident that the "bread" is actually a golden vessel with a grid pattern in its interior and is like the chalices depicted in oblique view (fig. 11). The strange slanting of both sides of the altar is a detail known from a late Byzantine example of the scene published by Klaus WESSEL in his monograph on the Last Supper in 1964 that also appeared in English translation (fig. 13). ${ }^{172}$ The short cloth covering the altar is also a strange detail because altar clothes in Byzantine art reach to the ground almost without exception. The drapery folds of the cloth on the Menil paten seems to be derived from the altar cloth depicted on the Riha paten (fig. 1). The pose of Christ holding a chalice in his left hand and distributing a piece of bread with his right hand is remindful of the miniature of the Communion of the Apostles in the Rabbula codex (fig. 8). The detail of putting the bread directly into the mouth (Mundkommunion) is not attested in the early Byzantine iconography of the scene and rarely after iconoclasm. ${ }^{173}$ The laying of the bread on the tongue is attested at first by Jacob of Edessa (ca. 633-707) for the Miaphysite church of western Syria but this practice was not widespread in the seventh century. ${ }^{174}$ In addition, the drapery of Peter's garment is misunderstood, clumsy and not corresponding to the high quality of the heads. The position of

170 Sotheby's (as footnote 168 above), 188. On the Emesa vase see C. METZGER, Nouvelles observations sur le "vase d'Emèse" et la "plaque de saint Syméon", in Boyd/Mundell Mango, Ecclesiastical silver plate (as footnote 7 above), 107-109 figs. 1-8. 10-11; Mundell MANGo, Silver (as footnote 1 above), 255 no. 84.

171 James, Mosaics (as footnote 148 above), $217 \mathrm{f}$. fig. 83; Hawkins/Mundell, Mosaics (as footnote 147 above), 289 f. figs. A. $33-35$.

172 WESSEL, Abendmahl (as footnote 2 above), 78. The English translation appeared under the title The Last Supper.

173 In the monograph of WeSSEL, Abendmahl (as footnote 2 above), 75.77 only one example is published with illustration, an eleventh-century icon in the monastery of Saint Catherine at Mount Sinai. http://vrc.princeton.edu/sinai/items/show/7462 (viewed July 12th 2021).

174 B. CASEAU, Die Aufgabe der Handkommunion. 4. - 12. Jahrhundert n.Chr., trans. A. WiTTENBURG. Trivium 27 (2017), 1-20: 6. https://journals.openedition.org/trivium/5607 (published at first as: L'abandon de la communion dans la main (IVe-XIIe siècles), in: Mélanges Gilbert Dagron. TM 14 (2002), 79-94. - Written testimonies suggest that the laying of the Eucharistic bread on the tongue became common for the communion for the laity by the ninth century. O. NussBaum, Die Handkommunion. Köln 1969, 25 - 31. 


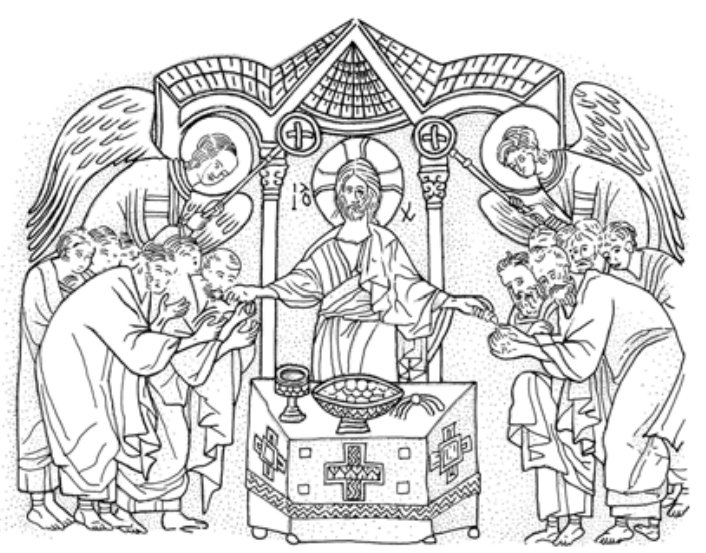

Fig. 13. Motive of the embroidery at Mount Athos, Chelandari monastery [drawing M. Ober, RGZM after Treasures of Mount Athos. Thessaloniki 21997, 472].

his right arm is also strange as it seems to be too short. Christ's hair dress with two rows of thick curls is closely related to the hairstyle of Saint Sergius on a silver bowl from the first Lambousa treasure. ${ }^{175}$

The similarities to well-known prototypes and the inconsistencies in iconography and style make the piece suspicious to be a fake although cracks, traces of corrosion and a reputed "old" mount ${ }^{176}$ are emphasized to support its ancient date. Actually, an investigation of the embrittlement of the piece by R.J.H. WANHILL suggests corrosion over a longer period. ${ }^{177}$ But even if the silver plate was old, the depiction might have been added recently to raise its value on the art market. However, a detailed analysis of the manufacturing technique, the chemical composition of the alloy, and a lead-isotope analysis $\left({ }^{210} \mathrm{~Pb}\right.$-test $)$ might produce further indications for authenticity. Until such data is available this piece is to be treated cautiously in any art historical assessment.

The authenticity of the silver plate with the depiction of the Communion of the Apostles in the collection of James Ferrell (fig. 14) is also dubious. The piece

175 London, British Museum inventory no. 1899.0425.2. On the plate see R. CoRMACK / M. VASSILAKi (eds.), Byzantium 330 - 1453. London 2008, 388f. no. 45 (M. Mundell MANGo); CruiKSHANK DodD, Silver stamps (as footnote 8 above), $220 \mathrm{f}$. no. 78.

176 SotheBY's (as footnote 168 above), 189.

177 R.J.H. WANHILL, Embrittlement of ancient silver. Journal of Failure Analysis and Prevention 5, 1 (2005), 41-54: $48 \mathrm{f}$. 


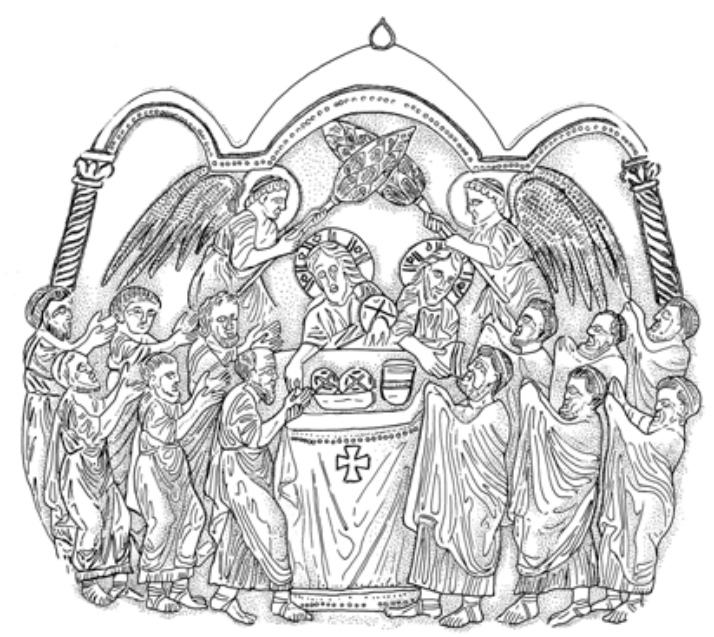

Fig. 14. Motive on the paten in the collection of James Ferrell [drawing M. Ober, RGZM after J. Spier, Treasures of the Ferrell Collection. Wiesbaden 2010, 259].

was made know to the public in 2010 from the catalogue of the collection. ${ }^{178}$ It resembles the type and decoration of the Stuma and Riha patens, although it differs in a number of details. There is no secure information regarding the provenance of the piece. ${ }^{179}$ It is dated by imperial stamps to the years $547-550 .{ }^{180}$ Its perfect condition without any visible damage and the "fresh" gilding showing no traces of friction are indications that the piece might be a modern forgery. This suspicion would also explain some strange details of the iconography that is obviously a pasticcio of the Stuma and Riha patens, and inspired by other wellknown examples of the scene. The triple-arched structure in the background for example has no parallel in early Byzantine iconography. The vaulted structure in its centre belongs to a ciborium and is inspired by the ciborium of the Stuma paten with arches added at each side. By this a hybrid between a cibo-

178 J. SPIER, Treasures of the Ferrell Collection. Wiesbaden 2010, 258-261 no. 190.

179 Information provided by the antiquities dealer William Veres to Aljazeera.net suggests that the plate was part of a group of 22 Byzantine silver vessels discovered in 2001 in the northern Syrian village of Shiraz. According to this source Ferrell seems to have bought these items from the Lebanese antiques dealer Abbas Yaghi that year. See the articles by D. HeBditch and L. SMALLMAN: US millionaire linked to looted relics, published June 26th 2005 on www.in dymedia.org.uk/en/2005/06/314916.html and June 29th 2005 on www.lookingglassnews.org/ viewstory.php?storyid=1130 (viewed July 8th 2021).

180 SPIER, Ferrell collection (as footnote 178 above), 260. 
rium and a templon is created. This is obviously inspired by the abbreviated architecture depicted on a late Byzantine embroidery published in Klaus WESSEL's publication on the Last Supper and the Communion of the Apostles (fig. 13). ${ }^{181}$ The pose of Christ holding a loaf of bread before his chest is paralleled in two ninth-century miniatures published in the monograph of Klaus Wessel, too (fig. 10). ${ }^{182}$

Angels functioning as deacons holding rhipidia are introduced to the Communion of the Apostles as an innovation in the eleventh century. ${ }^{183}$ The pose of the antithetic angels holding rhipidia over Christ in the Ferrell paten is apparently also inspired by the aforementioned embroidery (fig. 13) ${ }^{184}$ while the peacock feathers of their rhipidia are based upon the Apostolic Constitutions, not a pictorial tradition. ${ }^{185}$ The figures of the angels are not executed completely. Their forwarded leg is "cut off” just before Christ's shoulder. As the silversmith was capable to execute overlapping figures as is the case with the apostles arranged in two overlapping rows this inconsistency seems odd. But the arm of the right angel overlapping the Christs' halo is a detail that contradicts a common rule of early Byzantine visual art: neither Christ nor the emperor is overlapped by any other person! ${ }^{186}$

The two patens share the imitation of prototypes accessible through publications and iconographic inconsistencies with a silver plate at the Musée d'Art et d'Histoire at Geneva. The plate was acquired in 1975 from the art market and is

181 WESSEL, Abendmahl (as footnote 2 above), $78 \mathrm{f}$. On this embroidery see also the exhibitions catalogue: Treasures of Mount Athos. Thessaloniki ${ }^{2} 1997,472$ no. 11.24 (M. THEOCHARIs).

182 WeSSEL, Abendmahl (as footnote 2 above), 24-26.

183 Lidov, Church decoration (as footnote 98), 385; WALTER, Art and ritual (as footnote 103 above), 215. See also footnote 31 above.

184 Angels bearing rhipidia are regularly attested in depictions of the communion of the apostles since the eleventh century (fig. 3): LOERKE, Monumental miniature (as footnote 12 above), figs. 20. 22. 24.

185 Const. Apost. 8.12.2 (ed. M. MetzGER, Les Constitutions Apostoliques 3. Introduction, texte critique, traduction et notes. SC, 336. Paris 1987, 178f.).

186 The figure of Christ is not overlapped by an apostle neither on the Riha nor Stuma paten. Not in a single case is Christ overlapped by an angel in other depictions of the Communion of the Apostles. On the mosaic at Kiev (fig. 3) the angels are overlapped by Christ. - For the imperial couple not overlapped by other persons in the mosaic panels in San Vitale at Ravenna see Dresken-Weiland, Mosaiken (as footnote 2 above), 149; J. EngEmann, Deutung und Bedeutung frühchristlicher Bildwerke. Darmstadt 1997, 131 f.; F.W. DeICHMANN, Ravenna. Hauptstadt des spätantiken Abendlandes, II 2. Wiesbaden 1976, $183 \mathrm{f}$. 
likewise of unknown provenance. ${ }^{187}$ Its decoration of the sacrifice of Abraham closely resembles a stone relief in the Archaeological Museum at Istanbul known since 1932 from publications. ${ }^{188}$ The plate is in excellent condition and its authenticity has been doubted for a long time. A few years ago, its modern date was proven by lead-isotope analysis of the silver alloy. ${ }^{189}$

To conclude: as the two pieces in the Menil and Ferrell Collection share the method of imitating well-known iconographic prototypes with the plate at Geneva while showing by some inconsistencies that the silversmith was not familiar with early Byzantine iconography and style down to the last detail they are both suspicious to be modern forgeries. Thus the Menil and the Ferrell patens must not be included in any discussion of the iconography of the scene of the Communion of the Apostles ${ }^{190}$ until their authenticity is definitely proven.

187 Inventory no. AD 2383. Antiquités paléochrétiennes et byzantines, IIIe-XIVe siècles. Collection du Musée d'art et d'histoire Genève. Collections Byzantines du MAH 2. Milan 2011, $334 \mathrm{f}$. no. 318 (M. MARTINIANI-REBER).

188 Inventory no. 4141. J.G. DECKERs/G. КосH, Repertorium der christlich-antiken Sarkophage 5. Konstantinopel, Kleinasien - Thracia, Syria, Palaestina - Arabia. Wiesbaden 2018, $34 \mathrm{f}$. no. $32 \mathrm{pl} .11,1$.

189 M. MARTINIANi-Reber/K. AnHeuSER, Le plat d'argent au sacrifice d'Abraham. Oeuvre byzantine ou falsification? Geneva n.s. 57 (2009), 27 -33. The content of the radioactive lead-isotope $\mathrm{Pb}-210$ in the silver alloy definitely proves a recent date as it is only detectable for ca 100 120 years after the ore has been smelted.

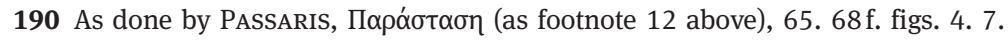


